\title{
Combination of a crop model and a geochemical model as a new approach to evaluate the sustainability of an intensive agriculture system
}

\author{
Gihan Mohammed ${ }^{1}$, Fabienne Trolard ${ }^{1, *}$, Marina Gillon ${ }^{1,}$, Anne-Laure \\ Cognard-Plancq ${ }^{1}$, André Chanzy¹, Guilhem Bourrié ${ }^{1,}$
}

\begin{abstract}
By combining a crop model (STICS) and a geochemical model (PHREEQC), a new approach to assess the sustainability of agrosystems is proposed. It is based upon aqueous geochemistry and the stepwise modifications of soil solution during its transfer from the surface till aquifer. Meadows of Crau (SE France), irrigated since the 16th century, were field monitored (2012-2015) and modelled. Except for $\mathrm{N}$, the mineral requirements of hay are largely covered by dissolved elements brought by irrigation water with only slight deficits in $\mathrm{K}$ and $\mathrm{P}$, which are compensated by $\mathrm{P}-\mathrm{K}$ fertilizers and the winter pasture by sheep. $\mathrm{N}$ cycle results in a very small nitrate leakage. The main determinants of the chemical composition changes of water are: concentration by evaporation, equilibration with soil $\mathrm{pCO}_{2}$, mineral nutrition of plants, input of fertilizers, sheep grazing, mineral-solution interactions in superficial formations till the aquifer, including ion exchange. Inverse modelling with PHREEQC allows for quantifying these processes. For groundwater, measured composition fit statistically very well with those computed, validating thus this approach. This long-term established agrosystem protects both soil and water resources: soil nutritional status remains constant with even some $\mathrm{P}$ and (minor) $\mathrm{K}$ fixation in soils; long-term decarbonatation occurs but it is greatly slowed by saturation of irrigation water by carbonate; $\mathrm{P}$ fixation in soil protects groundwater from eutrophication.

Keywords: Biogeochemical modelling, Mineral flux, Irrigation, Meadow, Water quality
\end{abstract}

\footnotetext{
${ }^{*}$ Corresponding author

Email addresses: gihan.mohammed@inra.fr (Gihan Mohammed), fabienne.trolard@inra.fr (Fabienne Trolard), marina.gillon@univ-avignon.fr

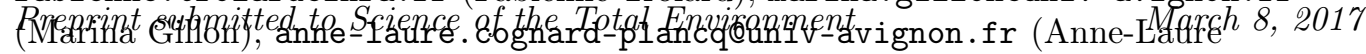
Cognard-Plancq), andre.chanzy@inra.fr (André Chanzy), guilhem.bourrie@inra.fr (Guilhem Bourrié)

${ }^{1}$ UAPV - INRA - UMR 1114 Emmah, Université d'Avignon, Domaine Saint-Paul, Site Agroparc, 84914 Avignon; France document 


\section{Introduction}

In the circumstances of global changes, i.e. urban sprawl and climate change, risks of degradation of natural and agricultural environments increase and territories become more vulnerable (Pachauri et al., 2007; Zhang et al., 2007; Pageaud and Carré, 2009; Olioso et al., 2013; Baillieux et al., 2015; Trolard et al., 2016). Climate change may positively or negatively impact the services provided by ecosystems on which our social systems depend (Trolard and Dangeard, 2014).

To ensure the resilience of a territory face to these changes, we must start from the concepts of limited space, scarce resources especially soil and water and integrate information (Trolard et al., 2013b).

It is recognized that irrigated systems can regulate the local climate, water resources and food security but little attention has been spent to the influence of nutrients in irrigation water, except in the special case of the application of treated wastewater for agricultural irrigation, which could provide nutrients and provide economic benefits (Cromer et al., 1984; Burau et al., 1987; Asano, 1998; Shuval, 1991; Oron et al., 1995; Lubello et al., 2004; Bixio et al., 2006; Tsiridis et al., 2009; Angelakis and Bontoux, 2001). Water scarcity and increase of costs of fertilizers make a more rigorous evaluation of water use in agriculture necessary.

Groundwater and surface water are not isolated. Thereby, any development or contamination of one normally affects the other and the general composition of rivers (Livingstone, 1963; Sophocleous, 2002; Goren et al., 2014). 
Irrigation water directly influences groundwater quality: nutrient fluxes were paid a lot of attention to (Valett et al., 1996; Dahm et al., 1998; Bourg and Bertin, 1993; Gibert et al., 1997; Sophocleous, 2002).

The processes at the interface between surface water and groundwater affect solute retention in streams (Valett et al., 1996) and lateral nutrient fluxes between uplands and aquatic ecosystems (Dahm et al., 1998; Wallis et al., 1981; Grimm and Fisher, 1984).

In coastal areas, phreatic water exerts a pressure on sea water to prevent salt intrusion and protects resource for drinking water, agricultural and industrial needs, including tourism (Mayer et al., 2016).

Other studies revealed that plant activity enriches the upper part of soils with inorganic elements used during growth (e.g.Si, K, Ca, Mg) (Jobbágy and Jackson, 2001; Lucas, 2001; Barré et al., 2009). Some studies have provided evidence of plants accelerating silicate weathering and $\mathrm{CO}_{2}$ consumption (Alexandre et al., 1997; Kelly et al., 1998; Moulton et al., 2000; Hinsinger et al., 2001; Song et al., 2011, 2012).

These studies point to the important role of plant to modify mineral balance of soil solution. Nevertheless, accounting for plant uptake is rather crude in biogeochemical modelling especially for daily uptake of inorganic elements by plants (Hartman et al., 2007).

In this context, the aim of this paper is to assess the sustainability of an intensive agricultural system under mediterranean to semi-arid climate.

The components of sustainability addressed here are: i) the short-term 
nutritional status of soils ; ii) the long-term tendency of soils towards decarbonatation and acidification, and iii) the quality of phreatic groundwater as a regional resource. Our approach combines a crop model (STICS) and a geochemical model (PHREEQC) and is based upon aqueous geochemistry to simulate the stepwise modifications of soil solution during its transfer from the surface till aquifer. Though PHREEQC is basically a geochemical model, it is here extended for the first time to simulation of uptake of elements by plants, and use of proton balance allows for taking into account the rhizosphere effect of acidification of soil solution.

\section{Modelling}

\subsection{State of the art on biogeochemical models}

Different models combine geochemical processes in agroecosystems, as illustrated in table 1. Most models have been developed for specific purposes: e.g. $\mathrm{N}$ and $\mathrm{C}$ cycles, acid rain or stress effects on forests.

Heat, water, nitrogen $(\mathrm{N})$ and carbon $(\mathrm{C})$ fluxes are simulated in many models of soil-plant-atmosphere system (Cramer et al., 2001; Morales et al., 2005; Yu et al., 2006; De Kauwe et al., 2013; Forster et al., 2013; Friedlingstein et al., 2014; Walker et al., 2014; Wenzel et al., 2014; Sándor et al., 2016; Senapati et al., 2016; Zhang et al., 2016), but do not pay attention to inorganic elements.

Nitrogen transport is studied through linking the hydrological flowpath and biogeochemical pathway in saturated / near-stream zones: this shows 
that surface / groundwater exchanges change rapidly on the timescale of hydrologic events, which controls the fate of N (Cirmo and McDonnell, 1997).

Solute retention in streams and lateral nutrient fluxes are modelled by linking hydrologic retention, biological nutrient cycling and chemical processes at the surface water / groundwater interface (Valett et al., 1996; Dahm et al., 1998).

Two models, PaSim and Biome-BGC MuSo, linking climate, soil, vegetation and management to ecosystem biogeochemical cycles were compared to simulate C cycle (Sándor et al., 2016), and fluxes between the terrestrial biosphere and the atmosphere in the context of the global change (Xiao et al., 2012; Cramer et al., 1999; Jung et al., 2007; Huntzinger et al., 2012).

Soil chemical and biological properties are combined to assess how nutrients cycling could be affected by wildfire (Fultz et al., 2016). The alpine hydrochemical model (AHM) gathered hydrological, geochemical, climatic and biogeochemical data sets to simulate daily stream chemical composition and its reaction to $\mathrm{N}$ deposition, but it cannot reflect terrestrial nutrient cycling (Meixner et al., 2000). SOILVEG and the combined FORGRO/NUCSAM gather biogeochemical and canopy processes to study effects of multiple stressors on forest stands, but they do not simulate stream chemistry (van Heerden et al., 1995; Mohren and van de Veen, 1995).

To capture ecosystem and surface water chemical response to atmospheric deposition and climate, biogeochemical model is established to simulate soil and surface water chemistry by linking ecosystem model (DayCent) with 
geochemical model (PHREEQC), nevertheless this model simulates only C, $\mathrm{N}, \mathrm{P}$, and $\mathrm{S}$ dynamics, there is no assimilation of cations $\left(\mathrm{Ca}^{2+}, \mathrm{Mg}^{2+}, \mathrm{K}^{+}\right)$ by plants (Hartman et al., 2007).

None of the preceding combination of models include both crop models for grassland ecosystems and biogeochemical models with their influence on soil solution and water quality.

Crop models can provide daily simulations of growth, but daily plant chemical analyses are very complicated and expensive to obtain.

\subsection{Biogeochemical processes}

Many processes influence the chemical composition of soil solution (Fig. 1): evapotranspiration, exchange of matter with soil and plants, inputs of fertilizers and manure (Mohammed et al., 2016b) and ion exchange. Thus it is necessary to acquire data on: i) the chemical composition of irrigation water and groundwater; ii) the nature and quantities of fertilizers and manure input on grassland soils; iii) the quantities of chemical elements harvested and exported during the various cuts of hay; iv) the effect of winter grazing meadows by sheeps, and v) $\mathrm{pCO}_{2}$ and temperature conditions in the soil.

The approach is based on combination of existing models, namely the crop model STICS, (Simulateur mulTIdisciplinaire pour les Cultures Standard) (Brisson et al., 2008) and the geochemical model PHREEQC (pH-REdoxEQuilibrium written in C language) (Parkhurst and Appelo, 2013) (Fig. 2). This interface is a part included in the general PRECOS framework approach 
(Trolard et al., 2016). Basic principles of both models are given below. STICS is a crop model, such as CERES, PANORAMIX, SUNFLO, PASIM, GRAECO (Brisson and Levrault, 2010). More specifically, STICS simulates the behavior of the soil-crop system in daily time step within 1 year. The upper limit of the system is the atmosphere characterized by standard climatic variables (solar radiation, minimum and maximum temperature, precipitation, reference evapotranspiration) and the lower limit corresponds to the soil/subsoil interface. STICS model is composed of seven modules: growth, development, shoot and root growth, yield components, thermal environment, water balance and nitrogen balance (Brisson et al., 2008). Leaf area index is a dynamic parameter used to simulate radiative budget, taking into account the morphology of plant cover. Carbon assimilation is simulated with detailed biochemistry of photosynthesis and gross respiration. The effect of $\mathrm{CO}_{2}$ on stomatal resistance is taken into account to compute the budget of radiative and convective energies. Water is transferred in soil to the underlying horizon as soon as water holding capacity is exceeded. For organic matter evolution, $\mathrm{N}$ cycle is first simulated, then $\mathrm{C}$ evolution is derived, by assuming a constant value of $\mathrm{C} / \mathrm{N}$ ratio (Brisson and Levrault, 2010).

STICS takes into account climate, soil characteristics, the type of crop and crop management. Its outputs are the production (yield and quality of biomass), and water and nitrogen balances. STICS was adapted for grassland (Ruget et al., 1999) and tested with success for various types of grasslands (Ruget et al., 2006). 
PHREEQC (Parkhurst and Appelo, 1999, 2013) is designed to perform a wide variety of low-temperature aqueous geochemical calculations. PHREEQC is based on an ion-association aqueous model and has capabilities for : (1) speciation and saturation-index calculations; (2) batch-reaction and onedimensional (1D) transport calculations involving reversible reactions, which include aqueous, mineral, gas, solid-solution, surface-complexation, and ionexchange equilibria, and irreversible reactions, which include specified mole transfers of reactants, kinetically controlled reactions, mixing of solutions, and pressure and temperature changes; and (3) inverse modelling, which finds sets of mineral and gas mass transfers that account for differences in composition between waters, within specified compositional uncertainty limits. It calculates the degree of saturation indexes $(S I=\log I A P-\log K(T))$, where $I A P$ is the Ionic Activity Product and $K$ is the equilibrium constant of the reaction at temperature $T$ for various minerals (calcite, gypsum etc.), changes in the water quality during its pathway through the soil, the amounts of dissolved or precipitated minerals, ion exchange and surface complexation phenomena.

In every case, PHREEQC can calculate changes in the chemical composition of the soil solution. PHREEQC takes thus into account the major geochemical processes that determine the water quality in a "water - plant soil - atmosphere" system (WPSA).

PHREEQC has been combined with hydrological models to simulate pro- 
cesses in deep aquifers, oil fields or geothermal energy production systems, assessment of contaminants or elements transport in watershed and to assess the hydrogeochemistry of seawater intrusion (Van Berk et al., 2009; Bozau et al., 2015; Papassiopi et al., 2014; Korrani et al., 2015; Garneau et al., 2017; Boluda-Botella et al., 2014; Rezaei et al., 2005), simulation of dissolved organic carbon (DOC) degradation using first-order kinetics, assuming two DOC fractions differing in reactivity (van Breukelen et al., 2004), and for predicting and designing biodenitrification applications including in the model microbiological processes - exogenous and endogenous nitrate respiration coupled to microbial growth and decay (Rodríguez-Escales et al., 2014). Inverse modelling was used to explain the modifications of the geochemistry of groundwaters of the three main aquifers of Sahara (Slimani et al., 2016).

\subsection{STICS Outputs used to interface with PHREEQC}

From climatic data, rainfall $P$, temperature $t$, irrigation $I$, and crop parameters, STICS calculates many parameters, of which a few are used here to interface with PHREEQC, namely: (i) evapotranspiration ET, (ii) the amount of water that drains below the root system into the deeper horizons of soil (drainage $D$ ), (iii) growth and the amount of biomass produced (yield $R)$.

All these output data, measured during the same time interval, are used to calculate the factor of water concentration by evaporation (Table 2) as : 


$$
f_{c}=\frac{P+I}{P+I-E T}=\frac{P+I}{D} .
$$

The $P, I, R$ and $D$ quantities provided by STICS allow for computing fluxes (mass/unit area) from concentrations of elements in plants (mass of element/kg of dry matter DM), in irrigation water, groundwater and soil solution (mass/volume of soil solution).

The flux of inorganic element exported by crop $\left(Q_{b}\right)$ is given by:

$$
Q_{b}=R[E]_{b},
$$

where $[E]_{b}$ is the concentration of an element $\mathrm{E}$ in plant (biomass) $\left(\mathrm{mol} \mathrm{kg}^{-1}\right.$ $\mathrm{DM})$, and $R$ the yield of exportation $\left(\mathrm{kg}\right.$ of $\left.\mathrm{DM} \mathrm{m}^{-2}\right)$, and $Q_{b}$ is in $\mathrm{mol} \mathrm{m}^{-2}$. The flux of inorganic element brought by irrigation water is given by:

$$
\begin{aligned}
Q_{p} & =P \rho_{w}[E]_{p}+I \rho_{w}[E]_{I}, \\
& \simeq I \rho_{w}[E]_{I},
\end{aligned}
$$

217 where $[E]_{p}$ is the concentration of an element in rainwater, $[E]_{I}$ is the concentration of an element in irrigation water $\left(\mathrm{mol} \mathrm{kg}^{-1}\right.$ of water), and $\rho_{w}$ is the specific mass of water $\left(\simeq 1 \mathrm{~kg} \mathrm{~L}^{-1}\right)$. Rainwater is here considered as 
contributing negligibly to the supply of elements to the system, except for a slight contribution for $\mathrm{N}$, taken as constant from STICS.

The flux of inorganic element exported by drainage $\left(Q_{d}\right)$ is given by:

$$
Q_{d}=\rho_{w} D[E]_{d},
$$

where $[E]_{d}$ is the concentration of an element in soil solution $\left(\mathrm{mol} \mathrm{\textrm {kg } ^ { - 1 }}\right.$ of water), $D$ the drainage ( $\mathrm{mm}=\mathrm{L} \mathrm{m}^{-2}$ of water), and $Q_{d}$ is in $\mathrm{mol} \mathrm{m}^{-2}$.

These equations are then used in PHREEQC simulation to calculate fluxes of elements between soil, plant and soil solution. Eventually they allow for computing the modifications of soil solution during its transfer through soil from its entry via the irrigation channel till groundwater.

\subsection{Proton balance}

Acid / base reactions influence $\mathrm{pH}$ by a variety of reactions: exchange of $\mathrm{CO}_{2}$ between solution, soil atmosphere and external atmosphere, calcite dissolution / precipitation, $\mathrm{N}$ cycle and through nutrients absorption by plants and excretion of protons in the rhizosphere. The rules for proton balance have been established long ago, more specifically following acid rain studies (Breemen et al., 1983; Bourrié and Lelong, 1990). The conservative function is alkalinity, which is a linear combination of concentrations of cations conjugate from strong bases and anions conjugate from strong acids (Stumm and Morgan, 1970; Bourrié, 1976). This linearity is conserved when converting 
concentrations into fluxes via eq. 3 to 4 . The flux of protons excreted by roots, i.e. the negative alkalinity flux into the solution, is implicitly modelled from the difference of bases uptaken and neutral salts uptaken as explained below, which takes thus into account the rhizosphere effect.

The influence of $\mathrm{N}$ cycle on the proton balance can be computed from the algebraic difference of fluxes : ([NH $\left.{ }_{4}^{+}\right]$in - $\left[\mathrm{NH}_{4}^{+}\right]$out $)-\left(\left[\mathrm{NO}_{3}^{-}\right]\right.$in - $\left[\mathrm{NO}_{3}^{-}\right]$out $)$ (Breemen et al., 1983).

Ammonification can be written as:

$$
\mathrm{R}-\mathrm{NH}_{2}+\mathrm{H}_{2} \mathrm{O}+\mathrm{H}^{+} \longrightarrow \mathrm{R}-\mathrm{OH}+\mathrm{NH}_{4}^{+}
$$

and nitrification as:

$$
\mathrm{NH}_{4}^{+}+2 \mathrm{O}_{2} \longrightarrow \mathrm{H}_{2} \mathrm{O}+\mathrm{NO}_{3}^{-}+2 \mathrm{H}^{+}
$$

so that the sum of reactions is:

$$
\mathrm{R}-\mathrm{NH}_{2}+2 \mathrm{O}_{2} \longrightarrow \mathrm{R}-\mathrm{OH}+\mathrm{NO}_{3}^{-}+\mathrm{H}^{+}
$$


releases a proton. However, absorption of nitrate at the root / solution interface releases an $\mathrm{OH}^{-}$in exchange, and therefore the proton balance is also zero. The balance is not zero for the topsoil if there are net fluxes either of $\mathrm{NH}_{4}^{+}$or of $\mathrm{NO}_{3}^{-}$output to groundwater, which is expressed in the algebraic difference as proposed by Breemen et al. (1983).

The amount of absorbed charge by plants is positive as dominated by $\mathrm{K}^{+}$ uptake. The plant compensates for this excess positive charge by the root proton transmission to the soil :

$\Sigma\left[\mathrm{H}^{+}\right]=\left[\mathrm{Na}^{+}\right]+\left[\mathrm{K}^{+}\right]+2\left[\mathrm{Ca}^{2+}\right]+2\left[\mathrm{Mg}^{2+}\right]+\left[\mathrm{NH}_{4}^{+}\right]-\left[\mathrm{H}_{2} \mathrm{PO}_{4}^{-}\right]-\left[\mathrm{NO}_{3}^{-}\right]-2\left[\mathrm{SO}_{4}^{-2}\right]$

so that the soil - plant system remains globally electrically neutral.

\subsection{PHREEQC simulation}

\subsubsection{Processes simulated by PHREEQC in this paper}

PHREEQC is used:

1. to compute saturation indexes $S I$ of solutions with respect to minerals that can dissolve or precipitate;

2. to simulate the modifications of the chemical composition of soil solution when it equilibrates with minerals, e.g. calcite and apatite and including $\mathrm{CO}_{2}$, as $\mathrm{CO}_{2(\mathrm{~g})}$ is formally treated as a mineral;

3. to simulate irreversible dissolution of P-K fertilizers; 
4. to simulate nitrification as an input of nitric acid into solution, according to reaction 7 , which is equivalent to nitric acid dissolution;

5. to simulate the removal of some constituents from the solution: water in order to simulate evaporation, specific minerals in order to simulate uptake of inorganic elements $(\mathrm{P}, \mathrm{K}, \mathrm{Ca}, \mathrm{Mg}, \mathrm{Na}, \mathrm{S})$ by plants, and nitric acid to simulate nitrate absorption by plants;

6. to compute by inverse modelling the best combination of geochemical processes that explain the transformations of the soil solution in the subsoil below the root system to groundwater.

\subsubsection{Dissolution of fertilizers and uptake by plants}

Dissolution of fertilizers and uptake by plants are respectively simulated as an addition or a removal of the corresponding electrically neutral component to soil solution, in the same way as evaporation is simulated with a negative coefficient for water. To avoid transient negative concentrations, fertilizer dissolution was simulated before absorption by plants.

Irreversible dissolution of fertilizers is simulated as dissolution of any mineral. The chemical composition of fertilizers is known and the mineral components are derived from the chemical and mineralogical analyses of fertilizers and from the nature of industrial processes: (i) inorganic $\mathrm{P}$ fertilizers consist of calcium di-hydrogen phosphate, $\mathrm{Ca}\left(\mathrm{H}_{2} \mathrm{PO}_{4}\right) \cdot 2 \mathrm{H}_{2} \mathrm{O}$, more soluble than apatite and obtained by acid attack of apatite by sulfuric acid, with gypsum $\mathrm{CaSO}_{4} \cdot 2 \mathrm{H}_{2} \mathrm{O}$, anhydrite $\mathrm{CaSO}_{4}$ and bassanite $\mathrm{CaSO}_{4} \cdot 0.5 \mathrm{H}_{2} \mathrm{O}$ as 
by-products; (ii) $\mathrm{K}$ fertilizers mainly consist of arcanite $\mathrm{K}_{2} \mathrm{SO}_{4}$, and sylvite $\mathrm{KCl}$; (iii) $\mathrm{N}$ input from $\mathrm{N}$ cycle is simulated as an input of nitric acid $\mathrm{HNO}_{3}$. The uptake of inorganic elements by plants is simulated here by PHREEQC as follows: (i) $\mathrm{P}$ absorption by plants is simulated as the removal of calcium di-hydrogen phosphate from the solution; (ii) S absorption by plants as the removal of gypsum; (iii) calcium being absorbed in excess of the sum of $\mathrm{P}$ and $\mathrm{S}$, the remaining $\mathrm{Ca}$ absorption is simulated as $\mathrm{CaO}$ removal from the solution ; (iv) $\mathrm{Na}, \mathrm{K}$ and $\mathrm{Mg}$ absorption by plants are simulated as the removal of $\mathrm{Na}_{2} \mathrm{O}, \mathrm{K}_{2} \mathrm{O}$ and $\mathrm{MgO}$ from the solution; (v) $\mathrm{N}$ uptake is simulated as nitric acid removal from the solution.

Calcium di-hydrogen phosphate, arcanite, sylvite, $\mathrm{Na}_{2} \mathrm{O}, \mathrm{K}_{2} \mathrm{O}, \mathrm{CaO}$ (lime), $\mathrm{MgO}$ (periclase) and nitric acid were introduced in PHREEQC database as PHASES; gypsum is already present in the database.

Activity coefficients were computed with Debye-Hückel extended law, as ionic strength is small enough $(\simeq 0.01 \mathrm{M})$. An example of calculation is given as supplementary material in annex.

\subsection{PHREEQC - STICS combination}

The modifications of the chemical composition of soil solution from the input in soil to its output to groundwater are simulated step by step. At each step, the integration time is long enough for the change in storage in soil $(\Delta S)$ to be negligible compared to the fluxes that pass through it; as a result soil solution is considered as a node (Bourrié and Lelong, 1990). In 
the case study (see below), the time step for crop growth is 1.5 to 2 months, which is the interval between two successive cuts.

Accordingly, the sum of fluxes entering solution (positive) is equal to the sum of fluxes leaving the solution (negative):

$$
Q_{p}+Q_{w}+Q_{b}+Q_{d}=0
$$

where $Q_{b}$ is the flux exported to plants (biomass), $Q_{d}$ the flux exported by drainage to the next node, $Q_{p}$ the input flux by irrigation water from the previous node and $Q_{w}$ the flux provided by fertilizers and / or mineral dissolution or precipitation. The boundary conditions fix the values of $Q_{p}$, inputs by irrigation and rain at the surface of soil and $Q_{d}$, drainage to groundwater below the root system, given by STICS.

The number of moles $(n)$ of dissolved fertilizers per $\mathrm{m}^{2}$ of irrigated meadow and relative to $1 \mathrm{~kg}$ of water that drains is derived by the following equations:

$$
Q_{w}=\nu_{E} n
$$

where $Q_{w}$ is the input flux by fertilizers, $\nu_{E}$ is the stoichiometric coefficient of element $\mathrm{E}$ in the fertilizer and $n$ is the number of moles of fertilizer dissolved per $\mathrm{m}^{2}$. This assumes that fertilizers dissolve stoichiometrically.

The mass balance for any element E can be written as: 


$$
I \rho_{w}[\mathrm{E}]_{I}+\nu_{E} n-R[\mathrm{E}]_{b}-D \rho_{w}[\mathrm{E}]_{d}=0 .
$$

We chose potassium to calibrate the model, supposing that there is no net fixation of $\mathrm{K}^{+}$in soil (ion exchange) during the interval of cuts (several months), or that it is negligible, if any; the composition of fertilizers is then conventionally related to $\mathrm{K}^{+}$, so that $\nu_{E}=1$ for $\mathrm{K}^{+}$. For $\mathrm{K}^{+}$, eq. 11 becomes:

$$
I \rho_{w}\left[\mathrm{~K}^{+}\right]_{I}+n-R\left[\mathrm{~K}^{+}\right]_{b}-D \rho_{w}\left[\mathrm{~K}^{+}\right]_{d}=0
$$

from which $n$ is derived as:

$$
n=D \rho_{w}\left[\mathrm{~K}^{+}\right]_{d}-I \rho_{w}\left[\mathrm{~K}^{+}\right]_{I}+R\left[\mathrm{~K}^{+}\right]_{b} .
$$

Data and parameters necessary for the simulation of changes undergone by irrigation water in the meadows are given in Table 2 .

The results are presented as graphs in which soil solution is considered as a node (Bourrié and Lelong, 1990) connecting different pools of elements (soil minerals, plants, fertilizers). 


\section{Material and methods}

\subsection{Case study}

The Crau area is the study case, that was monitored during four years (2012-2015). Situated in Provence (South-East of France), its climate is mediterranean with a rainfall average about $550 \mathrm{~mm} / \mathrm{yr}$. Since the 16 th century, water has been withdrawn from Durance River to this area, which has gradually constituted a dense network of channels (about $80 \mathrm{~km}$ long), hence enlarging irrigated area (Bonfillon, 2003). The Crau area is divided into i) the "dry Crau", which is occupied by a natural steppe (9,200 ha) and ii) the "wet Crau" that is an irrigated area, mostly occupied by permanent grasslands $(15,000$ ha). Irrigation contributes to about $70-80 \%$ of the total recharge of the aquifer (Bourrié et al., 2013; Olioso et al., 2013; Trolard et al., 2013a). Durance River deposited pebbles, which were cemented by calcium carbonate to form a pedogenetic puddingstone. Soils developed on this puddingstone are calcic luvisols (Bouteyre and Duclos, 1994), with a topsoil of $40 \mathrm{~cm}$ to $50 \mathrm{~cm}$ thick, containing a large content of pebbles (Colomb and Roux, 1978). The topsoil was progressively enriched in fine fractions due to silt input from the Durance River through irrigation period from April to September yearly till the 16th century.

Fertilization consists only of supplying $\mathrm{P}_{2} \mathrm{O}_{5}$ and $\mathrm{K}_{2} \mathrm{O}$ for first and second cuts (Diehl and Denoy, 1942; Mohammed et al., 2016a). N input is mainly due to symbiotic fixation by Legumes with some delayed inputs by manure. Yield income is by three hay cuts per year, in May, June-July and August- 
September respectively. In addition, a "fourth cut" is grazed directly by sheep in autumn and during the winter, but with a low value of digestibility. Thus the passage of sheep fertilizes grasslands with dung and urine, which represent a bulk mass of about 15 tons/ha to 30 tons/ha (Hugues et al., 1952). This area produces a high-value hay with a Certified Origin Product label (in french AOP), which is exported all around the world.

However, irrigated grassland areas in this study area are expected to decrease by $6 \%$ to $11 \%$ in 2030 , because of land uses change, specially urban sprawl, which jeopardizes the sustainability of groundwater and permanent grasslands, and reduction of irrigation by about $30 \%$ due to allocation changes of water to other activities such as urban and industrial areas (Trolard et al., 2013a, 2016).

\subsection{Crop model STICS operation}

Simulations with STICS were made using its regional version where every irrigated grass fields $(\simeq 7000$ plots in the Crau area) were simulated within a multisimulation framework. Climate data were given by a station located at the domaine du Merle managed by the INRA-Agroclim unit. Soils characteristics were derived from the Arles soil map (Bouteyre and Duclos, 1994), and the irrigation history: irrigation dates back to the 16th century, and extended steps by steps (Bonfillon, 2003). Due to the silt input by irrigation water, thickness of $A_{p}$ horizons increases with the age of irrigation (Trolard et al., 2016). Grass irrigation is made by flooding. Irrigation schedule is gov- 
erned by water turns between April to September, which are usually fixed every 10 days with an average intake of $200 \mathrm{~mm}$. To characterize the irrigation agenda and harvesting agenda for all fields, a stochastic model was implemented based on observations made in farms. Among the outputs, the harvested biomass $R$ and the drained water $D$ were used in the study. The yield estimates computed with STICS model were calibrated and validated on a set of 80 plots where data were collected and measured during four years (2006-2009) (Trolard et al., 2013b). The maximum uncertainties on parameters calculated by STICS model were $5 \%$ for irrigation quantity, $3 \%$ for biomass production and $10 \%$ for evapotranspiration.

\subsection{Data collection and analytical methods}

Meteorological data from INRA (Agroclim, Avignon) and Meteo France stations were used in STICS model (minimum and maximum temperatures, precipitation, solar radiation, wind speed and evapotranspiration of reference) to compute the yield $(R)$ and drainage $(D)$, for 2012-2015.

The data used in PHREEQC is the result of sampling field campaigns during four years (2012-2015): irrigation water, groundwater, chemical composition of hay, mineralogy and chemical composition of fertilizers, collection of historical chronicles (chemical analysis of hay, groundwater quality, climate data).

For waters, temperature, $\mathrm{pH}$ and electrical conductivity EC were measured in situ; samples were filtered at $0.45 \mu \mathrm{m}$ in the field; analyses of $\mathrm{K}^{+}$, 
$\mathrm{Ca}^{2+}, \mathrm{Na}^{+}, \mathrm{Mg}^{2+}$ were performed by atomic absorption spectrophotometry, $\mathrm{F}^{-}, \mathrm{Cl}^{-}, \mathrm{NO}_{3}^{-}, \mathrm{SO}_{4}^{2-}$ and $\mathrm{PO}_{4}^{3-}$ by ion chromatography, $\mathrm{SiO}_{2}$ by the molybdateblue method and alkalinity was measured by acidimetric titration following Gran's method (Gran, 1952). The maximum uncertainty for alkalinity was $0.01 \mathrm{mmol} / \mathrm{kgH}_{2} \mathrm{O}$ and $0.1 \mathrm{pH}$ unit for $\mathrm{pH}$. The analytical precision for the concentrations of major anions and cations ranges between 0.3 and $6.5 \%$.

For plants, analyses of major inorganic elements of the main families of plants were performed by ICP dry residues on the three cuts of 2015 (at INRA-USRAVE, Bordeaux laboratory, France). A database of the mineral composition of the hay since 1960 has been built from analysis reports conducted for the professional organization of Crau's hay Committee in accordance to the specifications of originally protected designation of COP (in french AOP) (Mohammed et al., 2016a).

For fertilizers, representative samples used in Crau were collected in 2014 and X-ray diffractometry was performed at ISTerre laboratory from Grenoble University. Chemical analyses of previous years were collected from the Crau's hay Committee (Comité du foin de Crau, 2014). Enquiries were made for fertilizer management, which supplied information about the inputs of fertilizers (see Supplemantary material).

\subsection{Goodness of fit}

To test the goodness of the model, different types of assessment methods were used to compare measured and simulated data. First, the correlation 
coefficient $R^{2}$ was computed; it describes the data dispersion compared to the prediction.Then the root mean square error (RMSE), that gives an overall assessment of the difference and the mean bias error $(M B E)$, that characterizes the bias of the difference, were used. Paired t-test was used by direct comparison between measured and simulated data using the null $\left(H_{0}\right.$ measured and simulated data are not significantly different) and alternative $\left(H_{1}\right)$ hypothesis. The Nash-Sutcliffe efficiency $(E F)$ was computed to determine the relative magnitude of the residual variance ("noise") compared to the measured data variance ("information") (Nash and Sutcliffe, 1970). It can range from $-\infty$ to 1 and an efficiency of $1(E F=1)$ corresponds to a perfect match between simulated and observed data.

Index of agreement $(d)$ is used to overcome the insensitivity of $E F$ and $R^{2}$ to differences in the observed and predicted averages and variances (Legates and McCabe, 1999); $d$ is the ratio of the mean square error and the potential error, its range is similar to that of $R^{2}$ and lies between 0 (no correlation) and 1 (perfect fit).

\section{Results and Discussion}

The chemical composition of irrigation water (Tables A1 to A5 in Supplementary material) shows only slight variations of $\mathrm{Na}^{+}, \mathrm{Cl}^{-}$and $\mathrm{SO}_{4}^{2-}$; $\mathrm{pH}, \mathrm{Ca}^{2+}$, alkalinity and $\mathrm{Mg}^{2+}$ are quasi-constant. Phosphate, fluoride and ammonium concentrations were smaller than the detection limits. Nitrate concentrations are small, but non negligible, which implies there is some N- 
leakage out of the system. Silica concentrations are small in between 2 and $5 \mathrm{mg} \mathrm{SiO}_{2} \mathrm{~kg}^{-1}$.

The chemical composition of groundwater shows even smaller variations; $\mathrm{pH}$ is lower, while inorganic $\mathrm{C}$ and $\mathrm{N}$ concentrations are larger than in irrigation water (Table A6 in Spuplementary material). The chemical composition of hay shows systematic variations: the contents of inorganic elements increase from Cut1 < Cut2 < Cut3 (Table A7 in Supplementary material) (Mohammed et al., 2016a).

\subsection{Mineral elements balances}

STICS outputs, yield $R$, drainage $D$ and factor of concentration of solution by evaporation $f_{c}$ are given in Table A8 (Supplementary material), time step considered is the interval between cuts, with three cuts per year. Using equations 2 and 3, fluxes brought by irrigation water $Q_{I}$ and exported by plants $Q_{b}$ were computed.

Mass balance calculations show that irrigation water meets the plant mineral needs except for $\mathrm{P}$ and $\mathrm{K}$ (Table 3).

\subsection{Check of equilibria with $\mathrm{CO}_{2}$, calcite and gypsum}

Saturation Indices of solutions with respect to $\mathrm{CO}_{2}(\mathrm{~g})$, calcite and gypsum were computed with PHREEQC. Positions of irrigation waters and groundwaters in equilibrium diagrams (Fig. 3) show that:

- irrigation waters are oversaturated with respect to calcite; 
- $\log$ of equilibrating partial pressure of $\mathrm{CO}_{2}$ for irrigation waters is $-3.25 \pm 0.07(n=12)$, i.e. $\simeq 0.056 \%$, which is slightly larger than atmospheric $\mathrm{pCO}_{2}, \simeq 0.035 \%$;

- groundwaters are close to equilibrium with respect to calcite $(S I=$ $0.1 \pm 0.05)$

- $\log$ of equilibrating partial pressure of $\mathrm{CO}_{2}$ for groundwaters is $-1.73 \pm 0.19$ $(n=36)$;

- all solutions are under-saturated with respect to gypsum.

The implications are : (i) pH is buffered by solid / soil solution carbonate equilibria, which limits the natural tendency of soils towards acidification; (ii) large concentrations of calcium are present in solution and in soil; (iii) water quality is good, and salinity hazard is very small.

\subsection{Simulations of the modifications of the composition of solution during} its transfer through soil

\subsubsection{Different steps of simulation}

Model is constrained by boundary conditions :

- input, irrigation water is slightly oversaturated with respect to calcite $(I S=0.76 \pm 0.06)$ as demonstrated above; this is due to the origin of Durance River from carbonated sediments (limestones, marls) in the Alps; 
- output to groundwater of P is null (ADES, 2016), whereas P inputs by fertilizers are necessary to complete P brought by irrigation. Indeed, farmers bring $\mathrm{P}-\mathrm{K}$ fertlizers with a slight excess of $\mathrm{P}$ with respect to $\mathrm{K}$; as $\mathrm{P}$ concentration in groundwater is null, this implies that $\mathrm{P}$ in excess precipitates in the subsoil. As the geochemical environment is close to equilibrium with calcite, the most likely form of $\mathrm{P}$ precipitation is hydroxyapatite. This prevents phosphate to be transferred to groundwater, which would result in eutrophication as there is some nitrate leakage.

The simulations of soil solution are divided into four main steps represented by four nodes (S) in the graph. Firstly, at S1 node (Fig. 4) irrigation water concentrates by evaporation and equilibrates with soil atmosphere $p \mathrm{CO}_{2}=2 \times 10^{-2}$ bar. This last value is derived from groundwater SI computed by PHREEQC: as observed above, $\log \mathrm{pCO}_{2}$ in phreatic groundwater shows very limited variations around -1.7 . We consider that irrigation water saturates soil pore space and infiltrates quickly. This limitates $\mathrm{CO}_{2}$ diffusion to external atmosphere, and water stays in equilibrium with $\mathrm{CO}_{2}$ - soil atmosphere from the topsoil till the aquifer.

Then, at S2 and S3 nodes, soil solution equilibria are computed after dissolution of mineral fertilizers (N, P, K, Ca, S) and uptake of inorganic elements by plants, respectively. Finally at node S4, the soil solution drains below the root zone and relaxes to equilibrium with calcite and hydroxyapatite. The work flow used for simulation in four steps is given in Fig. A5 in 
Supplementary material.

\subsubsection{Reference simulation: first cut 2015}

For exemple for the first cut in 2015, over these steps, graphs of Ca, $\mathrm{pH}$, inorganic $\mathrm{C}$ and $\mathrm{N}$ balances are detailed in fig. 4. The initial chemical composition of irrigation water is $1.683 \mathrm{mmol} \mathrm{kg}^{-1}$ of $\mathrm{Ca}, 3.176 \mathrm{mmol} \mathrm{kg}^{-1}$ of

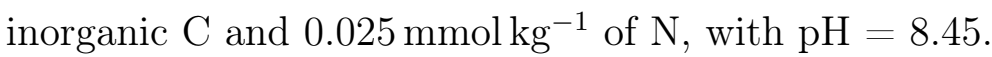

At S1 node, the irrigation water is diluted by rain water and then concentrated by evaporation. These two opposed effects directly determine the concentration factor $\left(f_{c}\right)$ according to eq. 1 so that $f_{c}=1.34$.

This leads to an increase of concentrations of $\mathrm{Ca}$, inorganic $\mathrm{C}$ and $\mathrm{N}$ in water by $f c=1.34$ respectively to $2.255 \mathrm{mmol} \mathrm{kg}^{-1}$ for Ca, to $4.256 \mathrm{mmol} \mathrm{kg}^{-1}$ for inorganic $\mathrm{C}$ and to $0.034 \mathrm{mmol} \mathrm{kg}^{-1}$ for $\mathrm{N}$. This leads to an increase of alkalinity with the same multiplying factor. As $\mathrm{pH}$ is an increasing function of alkalinity, $\mathrm{pH}$ is thus expected to increase, and consequently calcite is expected to precipitate.

However, simultaneously, during infiltration in the topsoil (Horizon A), irrigation water equilibrates with $\mathrm{pCO}_{2}$ of the soil atmosphere, which is much larger than $\mathrm{pCO}_{2}$ in external atmosphere due to organic matter oxidation in the soil. Therefore, changes in the chemical composition of water are the result of two opposite processes:

- concentration by evaporation of a saturated water tends to favor the increase of $\mathrm{pH}$ (Harvie and Weare, 1980), since the alkalinity is positive, 
and to precipitate calcite;

- dissolution of $\mathrm{CO}_{2}$ tends to lower the $\mathrm{pH}$ and dissolve calcite.

The simulation shows that this latter phenomenon dominates: a small amount of $\mathrm{CO}_{2}$ dissolves and provides $0.137 \mathrm{mmol}$ of $\mathrm{C}$ and leads to calcite dissolution that provides $0.432 \mathrm{mmol}$ of Ca. These modifications keep the soil solution in equilibrium with calcite, although irrigation water was initially over-saturated, and can be explained by the fact that the residual alkalinity of calcite in irrigation water is negative (Al-Droubi et al., 1980). As a result $\mathrm{pH}$ decreases to 7.13 .

Then this solution is brought back to $1 \mathrm{~kg}$ of water by identically mixing the resulting solution with itself, in order to keep the mass reference to $1 \mathrm{~kg}$ of water. Thereafter, the volume of water does not change and the concentrations can be directly compared with groundwater composition.

Statistical Student test $(P=0.05, \nu=36$, Table A9 in Suplementary material) shows that composition of soil solution at node 1 is not significantly different from groundwater for $\mathrm{Na}^{+}, \mathrm{Cl}^{-}, \mathrm{SO}_{4}^{2-}, \mathrm{K}^{+}$and $\mathrm{pH}$; it is significantly different for inorganic $\mathrm{C}, \mathrm{Mg}^{2+}$ and $\mathrm{Ca}^{2+}$ and even more for $\mathrm{NO}_{3}^{-}$, as nitrate concentration is ten times larger in groundwater as compared to irrigation water.

This means that: (i) even before taking into account fertilizers dissolution and uptake by plants, for most major elements, by equilibrating with soil atmosphere $\mathrm{pCO}_{2}$ and concentrating by evaporation, soil solution becomes very 
close to groundwater and (ii) that some significant, though minor, changes occur during its transfer through soil and puddingstone. These changes are then simulated to improve the fits.

Hereafter simulation of water quality divides into two steps, first inputs of inorganic elements are added to the solution from fertilizers and manure (node S2), secondly elements are removed from the solution by plants (node S3). At S2 node, dissolution of fertilizers adds $0.147 \mathrm{mmol} \mathrm{Ca}$. The amount of dissolved fertilizer was fitted on the concentration of $\mathrm{K}^{+}$in groundwater, and it was simply assumed that fertilizers dissolve proportionally to the average composition of the P-K fertilizer. This results in a slight excess of $\mathrm{P}$ addition, as the ratio $\mathrm{P} / \mathrm{K}$ in fertilizers added is larger than the ratio $\mathrm{P} / \mathrm{K}$ in the plant requirement.

At S3 node, roots absorb $0.236 \mathrm{mmol} \mathrm{Ca}$ and other nutrients, excreting $\mathrm{H}^{+}$, which acidifies the solution: $\mathrm{pH}$ decreases to 6.7. Fertilizer application quasi-exactly compensates nutrient requirements.

Finally at S4 node, the drainage water before reaching the groundwater equilibrates with respect to calcite, hydroxy-apatite and $\mathrm{pCO}_{2}$, as this was the boundary conditions fixed : (i) calcite dissolution occurs, which adds $0.444 \mathrm{mmol} \mathrm{Ca}$ and $\mathrm{C}$, and (ii) slight amount of $\mathrm{P}$ reaches the groundwater, which is simulated as precipitation as hydroxy-apatite (Table 4); the simulation of apatite precipitation is quantified as an irreversible fixation of $0.016 \mathrm{mmol} \mathrm{Ca}$; (iii) degassing releases $0.636 \mathrm{mmol} \mathrm{CO}_{2}$, which leads to increase $\mathrm{pH}$ to 7.11 . 


\subsubsection{Results for second and third cuts}

The results obtained for the second cut (Cut2) are similar to the results for the first cut (Cut1), but this is not the case for the third cut (Cut3) (see graphs Fig. A1 to A4 in Suplementary material). The major difference is that there is no addition of industrial fertilizers, whereas dissolved (P-K) from grazing manure added in winter, becomes progressively available (Kang and Freeman, 1999).

\subsubsection{Graphs of mass balances and $p H$}

Graphs of mass balances of $\mathrm{Ca}$ and inorganic $\mathrm{C}$ and of $\mathrm{pH}$ changes were drawn for the three cuts and four years (Fig. in supplementary materials). They show the sequence of geochemical processes that modify the chemical composition of water from irrigation water to groundwater. It appears that the irrigated agricultural system has the side effect of buffering $\mathrm{pH}$ of soil solution by bringing carbonate; moreover, both in the topsoil and in the subsoil, calcite dissolves: $\mathrm{pH}$ is buffered by equilibrium with calcite in a $\mathrm{pH}$ range from 7 to 8.3, depending on the partial pressure of $\mathrm{CO}_{2}$ in soil. Carbonate input by irrigation water amounts to $75 \%$ of the carbonate content of groundwater. This has a positive effect in maintaining soil quality and fertility, as it opposes to the general geochemical tendency to decarbonatation in the north of Mediterranean sea, to acidification and degradation of clay minerals and soil structure.

Irrigation can affect soil carbon storage by altering both soil organic car- 
bon (SOC) and soil inorganic carbon (SIC) cycling (Hannam et al., 2016).

Here, we only discuss soil inorganic carbon.

During the water quality transformation, which takes place in the upper horizon of soil (Horizon A), irrigation water dissolves calcite and $\mathrm{CO}_{2, \mathrm{~g}}$ of the soil atmosphere to maintain the soil solution at equilibrium with calcite, although irrigation water was initially supersaturated with respect to calcite. For 2015 Cut 1, to obtain $1 \mathrm{~L}$ of groundwater, irrigation water starts with $1.34 \mathrm{~L}$, and therefore $1.37 \mathrm{mmol}$ of $\mathrm{CO}_{2}(\mathrm{~g})$ of the soil atmosphere is trapped. Then, the solution re-equilibrates with the calcite, since there is a stock of "active limestone" in soil and in the calcrete (locally termed "taparas"). As a result, $0.444 \mathrm{mmol}$ of calcite dissolve and $0.635 \mathrm{mmol}$ of $\mathrm{CO}_{2, \mathrm{~g}}$ degas, which returns to the soil atmosphere per $1 \mathrm{~kg}$ of drained water below the root system.

The balance is that $0.735 \mathrm{mmol}$ of $\mathrm{CO}_{2, \mathrm{~g}}$ per $1 \mathrm{~kg}$ of drainage water is dissolved and transformed into $\mathrm{HCO}_{3}^{-}$anion and drained to the groundwater. The soil solution therefore plays here locally the role of $\mathrm{CO}_{2}$ sink. However, this results from calcite dissolution:

$$
\mathrm{CaCO}_{3}+\mathrm{CO}_{2}+\mathrm{H}_{2} \mathrm{O} \longrightarrow \mathrm{Ca}\left(\mathrm{HCO}_{3}\right)_{2},
$$

and calcite is expected to precipitate later, either in the subsoil or in the sedimentary basin. Then the reverse reaction will occur, so that ultimately the small amount of $\mathrm{CO}_{2}$ trapped in soil will be released to atmosphere. The 
net balance is thus zero, and this does not act globally as a carbon sink. Only calcium originating from Ca-silicates weathering can trap $\mathrm{CO}_{2}$ from the atmosphere.

\subsection{Simulated and measured data}

\subsubsection{Global fit}

The excellent correlation $\left(R^{2} \geq 0.956\right)$ obtained between measured and simulated values of groundwater validates the proposed approach. This is illustrated in Fig. 5 and Table in Annex, with the results of statistical tests of goodness of fits. A further scrutiny of Fig. 5 shows that all elements are close to the 1:1 line. $\mathrm{K}$ cannot be used for validation, as it was used to fit the number of moles of fertilizers dissolved and our model was fitted on the concentration of $\mathrm{K}^{+}$in groundwater. $\mathrm{Na}^{+}, \mathrm{Cl}^{-}, \mathrm{SO}_{4}^{2-}$ and inorganic $\mathrm{C}$ do not show any appreciable deviation. Instead, $\mathrm{Ca}$ and $\mathrm{Mg}$ show a slight but net deviation. The differences (Table 5) are nearly exactly opposite, with $\left[\mathrm{Ca}^{2+}\right]$ being slightly underestimated $\left(\Delta=0.237 \mathrm{mmol} \mathrm{kg}^{-1}\right)$ and $\left[\mathrm{Mg}^{2+}\right]$ being slightly overestimated, $\left(\Delta=0.234 \mathrm{mmol} \mathrm{kg}^{-1}\right)$. The discrepancy for Ca could neither be solved by modifying $\mathrm{pCO}_{2}$ in the simulation, nor by allowing calcite to precipitate with some oversaturation degree. This would lead to a poorer fit for inorganic C. It is thus likely that some Mg is fixed in soil and some Ca released in the solution by ion exchange on clay minerals or exchange sites of organic matter, which was not included in the direct simulation above. 


\subsubsection{Inverse modelling}

Inverse modelling was used to simulate the modification from node S3, just after plant uptake, to groundwater, by introducing ion exchange, and letting all minerals, i.e. calcite, hydroxy-apatite and $\mathrm{CO}_{2(\mathrm{~g})}$ free to dissolve or precipitate, $\mathrm{CO}_{2(\mathrm{~g})}$ being formally treated as a mineral. PHREEQC can compute the amounts of dissolved or precipitated minerals that account better to explain the transformation of soil solution at S3 node into groundwater. The results show that ion exchange contributes to Ca release $\left(3 \times 10^{-4} \mathrm{~mol} \mathrm{~kg}^{-1}\right.$ of water), against $\mathrm{Mg}\left(-2 \times 10^{-4} \mathrm{~mol} \mathrm{~kg}^{-1}\right.$ of water $), \mathrm{Na}\left(-2 \times 10^{-4} \mathrm{~mol} \mathrm{~kg}^{-1}\right.$ of water) and quite negligible $\mathrm{K}\left(-5 \times 10^{-6} \mathrm{~mol} \mathrm{~kg}^{-1}\right.$ of water $)$ fixation; some $\mathrm{CO}_{2(\mathrm{~g})}$ escapes and excess $\mathrm{P}$ precipitates as apatite. All fits are better than $10 \%$ agreement between groundwater simulated and observed (Table 5).

\subsection{Sustainability}

Due to its chemical composition, irrigation water supplies most of nutrients necessary to hay growth. It is completed by some $\mathrm{P}, \mathrm{K}$ fertilizers and $\mathrm{N}$ input from manure and recycling of $\mathrm{N}$ from soil organic matter. A slight excess of $\mathrm{P}$ precipitates as hydroxy-apatite in the soil or subsoil. Ion exchange fix some $\mathrm{Mg}$ and $\mathrm{Na}$ against some $\mathrm{Ca}$ release, with a quasi-negligible $\mathrm{K}$ fixation, which justifies our hypothesis to fit the amount of fertilizers dissolved on K output.

Globally, some calcite dissolves, which is the general tendency. It is slower than it would be under rainwater input alone, as irrigation water originates 
from the Alps, where limestones are abundant.

The nutrient status of soils is thus preserved, with some enrichment in $\mathrm{P}$ and stability of $\mathrm{K}$ status, in a context of possible decrease of the availability of $\mathrm{P}$ and $\mathrm{K}$ resources at a global level.

Groundwater quality is preserved, with a small leakage of nitrate, but $c a$. $9 \mathrm{mg} \mathrm{N}$ Liter $^{-1}$, which is much smaller than the limit for drinking water. P is retained in soil, which prevents from eutrophication.

The present agro-ecosystem preserves thus both soil and water resources, in a region submitted to large pressures from urban sprawl, in the immediate vicinity of Marseilles, Arles and several cities. It dates back to the 16th century and is the basis for many labelled productions (hay, lamb, wool...). It appears thus as a sustainable and productive agro-ecosystem.

\section{Conclusions}

The combination of a crop model STICS and a geochemical model PHREEQC allows for modelling and quantifying the changes in chemical composition of water from the surface till the aquifer by including together data from agronomy, climatology, geochemistry and soil science. The approach consists to: (i) compute step by step the successive modifications of the chemical composition of water, considered as a node from its input in the agrosystem till the groundwater in the aquifer; (ii) introduce the plant uptake in the geochemical model PHREEQC; (iii) compute the flux and the mass balance for all chemical elements and parameters defining the water and soil quality of 
agrosystem, and (iv) use PHREEQC as inverse model to quantify geochemical processes below the root zone.

The proposed model was tested and validated on four years of cultivation of hay and for each cut per year in Crau area.

Results show that the main determinants of the chemical changes of water composition during its transfer through soil are: concentration by evaporation, equilibration with $\mathrm{pCO}_{2}$ of soil atmosphere, mineral uptake by plants, input of fertilizers, grazing by sheep during the winter and mineral-solution interactions in superficial formations, including ion exchanges, till the aquifer. Except for N, the mineral requirements of hay are largely covered by dissolved elements brought by irrigation water with only slight deficits in $\mathrm{K}$ and $\mathrm{P}$, which are compensated by P-K fertilizers and the pasture by sheep during winter. For groundwater, measured composition fit statistically very well with those computed, validating thus this approach.

This long-term established agrosystem protects both soil and water resources: soil nutritional status remains constant with even some enrichment in $\mathrm{P}$ as apatite precipitation in soil or subsoil, a net $\mathrm{Mg}$ fixation and a slight $\mathrm{K}$ fixation (at least a stability) on exchange sites; long-term decarbonatation occurs as is the rule north of Mediterranean sea and in temperate climate, but it is largely slowed by the input of dissolved carbonate in irrigation water, originating from Alps's limestones; groundwater quality is preserved from eutrophication by $\mathrm{P}$ fixation in soil due to the large concentration of $\mathrm{Ca}$ in 
solution and in soil.

Aqueous geochemistry of this agrosystem reveals that irrigation via Durance River provides beneficial effects such as savings of fertilizers, protection of soil minerals against natural tendency to acidification, groundwater recharge and control of groundwater quality. In addition it contributes to production of a high quality forage (COP, in french AOP). This long-terme crop system established back to the 16th century can thus be considered as a remarkable instance of ecologically intensive agriculture.

\section{Acknowledgements}

We are grateful to the farmers in Crau, MM. Blanc and Jarrige, for the generous access to their grasslands, to François Charron, Deputy Director of the experimental domain (Le Merle, SupAgro Montpellier) and to Milanka Babic, Fabrice Flamain and Ghislain Sevenier for their help with the sampling and laboratory analysis. We sincerely thank Françoise Ruget and Patrice Lecharpentier for their help in crop model simulations and Bruno Lançon from ISTerre, Grenoble University for the acquisition of X-ray diagrams on fertilizers. The support of Climate KIC (PRECOS programm) is gratefully acknowledged. Three anonymous reviewers are thanked for theiruseful comments and pertinent remarks on the content of the paper. They contributed to improve the quality and legibility of this paper. 


\section{References}

ADES, 2016. Portail national d'accès aux données sur les eaux souterraines. URL: //http://www.ades . eaufrance.fr/.

Al-Droubi, A., Fritz, B., Gac, J.Y., Tardy, Y., 1980. Generalized residual alkalinity concept; application to prediction of the chemical evolution of natural waters by evaporation. American Journal of Science 280, 560-572.

Alexandre, A., Meunier, J.D., Colin, F., Koud, J.M., 1997. Plant impact on the biogeochemical cycle of silicon and related weathering processes. Geochimica et Cosmochimica Acta 61, 677-682.

Angelakis, A., Bontoux, L., 2001. Wastewater reclamation and reuse in eureau countries. Water Policy 3, 47-59.

Asano, T., 1998. Wastewater Reclamation and Reuse: Water Quality Management Library. volume 10. CRC Press.

Baillieux, A., Olioso, A., Trolard, F., Chanzy, A., Lecerf, R., Lecharpentier, P., Banton, O., Ruget, F., Ruy, S., 2015. Changements globaux : quels impacts sur l'aquifère de la Crau ? Géologues (Paris) , 85-92.

Barré, P., Berger, G., Velde, B., 2009. How element translocation by plants may stabilize illitic clays in the surface of temperate soils. Geoderma 151, $22-30$. 
Bixio, D., Thoeye, C., De Koning, J., Joksimovic, D., Savic, D., Wintgens, T., Melin, T., 2006. Wastewater reuse in Europe. Desalination 187, 89-101.

Boluda-Botella, N., Valdes-Abellan, J., Pedraza, R., 2014. Applying reactive models to column experiments to assess the hydrogeochemistry of seawater intrusion: optimising acuaintrusion and selecting cation exchange coefficients with phreeqc. Journal of Hydrology 510, 59-69.

Bonfillon, M.S., 2003. Le canal de Craponne un exemple de mâitrise de l'eau en Provence occidentale. Ph.D. thesis. Aix-Marseille University.

Bourg, A.C., Bertin, C., 1993. Biogeochemical processes during the infiltration of river water into an alluvial aquifer. Environmental Science \& Technology 27, 661-666.

Bourrié, G., 1976. Relation entre le pH, l'alcalinité, le pouvoir tampon et les équilibres de $\mathrm{CO}_{2}$ dans les eaux naturelles. Science du Sol 3, 141-159.

Bourrié, G., Lelong, F., 1990. Formalization of proton balances in elementary basins based upon the alkalinity concept and graph properties, in: Lang, H., Musy, A. (Eds.), Hydrology in Mountainous Regions. I - Hydrological Measurements; the Water Cycle. International Association of Hydrological Sciences, Wallingford, U.K.. number 193 in IAHS Publication, pp. 703-712.

Bourrié, G., Trolard, F., Chanzy, A., Ruget, F., Lecerf, R., Charron, F., 2013. Sustainable intensive agriculture: Evidence from aqueous geochemistry. PROCEDIA Earth and Planetary Science 7, 93-96. 
Bouteyre, G., Duclos, G., 1994. Carte pédologique de France au 1/100 000, Arles N-22. Notice explicative de la carte. Service d'étude des Sols et de la Carte pédologique de France, Orléans.

Bozau, E., Häußler, S., van Berk, W., 2015. Hydrogeochemical modelling of corrosion effects and barite scaling in deep geothermal wells of the north german basin using phreeqc and phast. Geothermics 53, 540-547.

Breemen, N.V., Mulder, J., Driscoll, C., 1983. Acidification and alkalinization of soil. Plant and Soil 75, 283-308.

van Breukelen, B.M., Griffioen, J., Röling, W.F., van Verseveld, H.W., 2004. Reactive transport modelling of biogeochemical processes and carbon isotope geochemistry inside a landfill leachate plume. Journal of contaminant hydrology 70, 249-269.

Brisson, N., Launat-y, M., Mary, B., Beaudoin, N., 2008. Conceptual basis, formalisations and parameterization of the STICS crop model. Quae.

Brisson, N., Levrault, F., 2010. Livre vert du projet CLIMATOR 2007-2010. ADEME.

Burau, R., Sheikh, B., Cort, R., Cooper, R., Ririe, D., 1987. Reclaimed water for irrigation of vegetables eaten raw. California agriculture 41, 3-7.

Cirmo, C.P., McDonnell, J.J., 1997. Linking the hydrologic and biogeochemical controls of nitrogen transport in near-stream zones of temperateforested catchments: a review. Journal of Hydrology 199, 88-120. 
Colomb, E., Roux, R.M., 1978. La Crau - Données nouvelles et interprétation. Géologie méditerranéenne V, 303-324.

Comité du foin de Crau, 2014. Le Foin de Crau. Technical Report. Comité de foin (AOP), Saint-Martin de Crau.

Cramer, W., Bondeau, A., Woodward, F.I., Prentice, I.C., Betts, R.A., Brovkin, V., Cox, P.M., Fisher, V., Foley, J.A., Friend, A.D., et al., 2001. Global response of terrestrial ecosystem structure and function to $\mathrm{CO} 2$ and climate change: results from six dynamic global vegetation models. Global change biology 7, 357-373.

Cramer, W., Kicklighter, D., Bondeau, A., Iii, B.M., Churkina, G., Nemry, B., Ruimy, A., Schloss, A., Intercomparison, T., Model, P.O.T.P.N., 1999. Comparing global models of terrestrial net primary productivity (npp): overview and key results. Global change biology 5, 1-15.

Cromer, R., Tompkins, D., Barr, N., Hopmans, P., 1984. Irrigation of monterey pine with wastewater: effect on soil chemistry and groundwater composition. Journal of Environmental Quality 13, 539-542.

Dahm, C.N., Grimm, N.B., Marmonier, P., Valett, H.M., Vervier, P., 1998. Nutrient dynamics at the interface between surface waters and groundwaters. Freshwater Biology 40, 427-451.

De Kauwe, M.G., Medlyn, B.E., Zaehle, S., Walker, A.P., Dietze, M.C., Hickler, T., Jain, A.K., Luo, Y., Parton, W.J., Prentice, I.C., et al., 2013. 
Forest water use and water use efficiency at elevated CO2: a model-data intercomparison at two contrasting temperate forest FACE sites. Global Change Biology 19, 1759-1779.

Diehl, M., Denoy, I., 1942. Researches about fertilization of irrigated meadows in Crau. Amélioration des plantes. Centre de recherche agronomiques du midi, Montpellier et domaine expérimental du Merle.

Forster, P.M., Andrews, T., Good, P., Gregory, J.M., Jackson, L.S., Zelinka, M., 2013. Evaluating adjusted forcing and model spread for historical and future scenarios in the CMIP5 generation of climate models. Journal of Geophysical Research: Atmospheres 118, 1139-1150.

Friedlingstein, P., Meinshausen, M., Arora, V.K., Jones, C.D., Anav, A., Liddicoat, S.K., Knutti, R., 2014. Uncertainties in CMIP5 climate projections due to carbon cycle feedbacks. Journal of Climate 27, 511-526.

Fultz, L.M., Moore-Kucera, J., Dathe, J., Davinic, M., Perry, G., Wester, D., Schwilk, D.W., Rideout-Hanzak, S., 2016. Forest wildfire and grassland prescribed fire effects on soil biogeochemical processes and microbial communities: Two case studies in the semi-arid southwest. Applied Soil Ecology 99, 118-128.

Garneau, C., Sauvage, S., Sánchez-Pérez, J.M., Lofts, S., Brito, D., Neves, R., Probst, A., 2017. Modelling trace metal transfer in large rivers under 
dynamic hydrology: A coupled hydrodynamic and chemical equilibrium model. Environmental Modelling \& Software 89, 77-96.

Gibert, J., Mathieu, J., Fournier, F., 1997. Groundwater/surface water ecotones: biological and hydrological interactions and management options. Cambridge University Press Cambridge.

Goren, O., Burg, A., Gavrieli, I., Negev, I., Guttman, J., Kraitzer, T., Kloppmann, W., Lazar, B., 2014. Biogeochemical processes in infiltration basins and their impact on the recharging effluent, the soil aquifer treatment (sat) system of the shafdan plant, israel. Applied Geochemistry 48, 58-69.

Gran, G., 1952. Determination of the equivalence point in potentiometric titrations. part II. Analyst 77, 661-671.

Grimm, N.B., Fisher, S.G., 1984. Exchange between interstitial and surface water: implications for stream metabolism and nutrient cycling. Hydrobiologia 111, 219-228.

Hannam, K.D., Kehila, D., Millard, P., Midwood, A.J., Neilsen, D., Neilsen, G.H., Forge, T.A., Nichol, C., Jones, M.D., 2016. Bicarbonates in irrigation water contribute to carbonate formation and $\mathrm{co}_{2}$ production in orchard soils under drip irrigation. Geoderma 266, 120-126.

Hartman, M.D., Baron, J.S., Ojima, D.S., 2007. Application of a coupled ecosystem-chemical equilibrium model, DayCent-Chem, to stream and soil 
chemistry in a Rocky Mountain watershed. ecological modelling 200, 493510.

Harvie, C., Weare, J., 1980. The prediction of mineral solubilities in natural waters: the $\mathrm{Na}-\mathrm{K}-\mathrm{Mg}-\mathrm{Ca}-\mathrm{Cl}-\mathrm{SO}_{4}-\mathrm{H}_{2} \mathrm{O}$ system from zero to high concentration at $25^{\circ} \mathrm{C}$. Geochimica et Cosmochimica Acta 44, 981-987.

van Heerden, K., van Grinsven, H.J., Tiktak, A., 1995. Simulation of forest stress for the solling spruce site with soilveg. Ecological Modelling 83, $185-195$.

Hinsinger, P., Barros, O.N.F., Benedetti, M.F., Noack, Y., Callot, G., 2001. Plant-induced weathering of a basaltic rock: experimental evidence. Geochimica et Cosmochimica Acta 65, 137-152.

Hugues, P., Denoy, I., Ferret, M., 1952. Flora evaluation and yield variation under effect of various mineral fertilizers. Amélioration des plantes. Centre de recherche agronomiques du midi, Montpellier et domaine experimental du Merle.

Huntzinger, D., Post, W.M., Wei, Y., Michalak, A., West, T.O., Jacobson, A., Baker, I., Chen, J.M., Davis, K., Hayes, D., et al., 2012. North american carbon program (nacp) regional interim synthesis: Terrestrial biospheric model intercomparison. Ecological Modelling 232, 144-157.

Jobbágy, E.G., Jackson, R.B., 2001. The distribution of soil nutrients with 
depth: global patterns and the imprint of plants. Biogeochemistry 53, 51-77.

Jung, M., Vetter, M., Herold, M., Churkina, G., Reichstein, M., Zaehle, S., Ciais, P., Viovy, N., Bondeau, A., Chen, Y., et al., 2007. Uncertainties of modeling gross primary productivity over europe: A systematic study on the effects of using different drivers and terrestrial biosphere models. Global Biogeochemical Cycles 21.

Kang, H., Freeman, C., 1999. Phosphatase and arylsulphatase activities in wetland soils: annual variation and controlling factors. Soil Biology and Biochemistry 31, 449-454.

Kelly, E.F., Chadwick, O.A., Hilinski, T.E., 1998. The effect of plants on mineral weathering, in: Plant-induced soil changes: Processes and feedbacks. Springer, pp. 21-53.

Korrani, A.K.N., Sepehrnoori, K., Delshad, M., 2015. Coupling iphreeqc with utchem to model reactive flow and transport. Computers \& Geosciences $82,152-169$.

Legates, D.R., McCabe, G.J., 1999. Evaluating the use of "goodness-offit" measures in hydrologic and hydroclimatic model validation. Water resources research 35, 233-241.

Livingstone, D., 1963. Data of géochemistry sixeth edition, chapter of chemical composition of rivers and lake. Unitaed stated, geological survey. 
Lubello, C., Gori, R., Nicese, F.P., Ferrini, F., 2004. Municipal-treated wastewater reuse for plant nurseries irrigation. Water Research 38, 29392947.

Lucas, Y., 2001. The role of plants in controlling rates and products of weathering: importance of biological pumping. Annual Review of Earth and Planetary Sciences 29, 135-163.

Mayer, A., Nguyen, B.T., Banton, O., 2016. Using radon-222 to study coastal groundwater/surface-water interaction in the crau coastal aquifer (southeastern france). Hydrogeology Journal 24, 1775-1789.

Meixner, T., Bales, R.C., Williams, M.W., Campbell, D.H., Baron, J.S., 2000. Stream chemistry modeling of two watersheds in the front range, colorado. Water resources research 36, 77-87.

Mohammed, G., Trolard, F., Bourrié, G., Gillon, M., Tronc, D., Charron, F., 2016a. A Long-Term Data Sequence (1960-2013) to Analyse the Sustainability of Hay Quality in Irrigated Permanent Grasslands Under Climate Change. American Journal of Agriculture and Forestry , 12.

Mohammed, G., Trolard, F., Bourrié, G., Trolard, F., Nofal, S., T., N.B., 2016b. Geochemical modeling of the system "Water-Soil-Plant " case study: Crau south France. ESASGD 2016, Available online at www.humg.edu.vn , 290-293. 
Mohren, G.M., van de Veen, J.R., 1995. Forest growth in relation to site conditions. application of the model forgro to the solling spruce site. Ecological Modelling 83, 173-183.

Morales, P., Sykes, M.T., Prentice, I.C., Smith, P., Smith, B., Bugmann, H., Zierl, B., Friedlingstein, P., Viovy, N., Sabate, S., et al., 2005. Comparing and evaluating process-based ecosystem model predictions of carbon and water fluxes in major european forest biomes. Global Change Biology 11, $2211-2233$.

Moulton, K.L., West, J., Berner, R.A., 2000. Solute flux and mineral mass balance approaches to the quantification of plant effects on silicate weathering. American Journal of Science 300, 539-570.

Nash, J., Sutcliffe, J., 1970. River flow forecasting through conceptual models part I-A discussion of principles. Journal of hydrology 10, 282-290.

Olioso, A., Lecerf, R., Baillieux, A., Chanzy, A., Ruget, F., Banton, O., Lecharpentier, P., Trolard, F., Cognard-Plancq, A.L., 2013. Modelling of drainage and hay production over the Crau aquifer for analysing impact of global change on aquifer recharge. Procedia Environmental Sciences 19, $691-700$.

Oron, G., Goemans, M., Manor, Y., Feyen, J., 1995. Poliovirus distribution in the soil-plant system under reuse of secondary wastewater. Water Research 29, 1069-1078. 
Pachauri, R., Reisinger, A., Team, C.W., 2007. Climate Change 2007 Synthesis Report. the Intergovernmental Panel on Climate Change. doi:10.1256/004316502320517344.

Pageaud, D., Carré, C., 2009. La France vue par CORINE Land Cover, outil européen de suivi de l'occupation des sols. Observation et statistiques .

Papassiopi, N., Zaharia, C., Xenidis, A., Adam, K., Liakopoulos, A., Romaidis, I., 2014. Assessment of contaminants transport in a watershed affected by acid mine drainage, by coupling hydrological and geochemical modeling tools. Minerals Engineering 64, 78-91.

Parkhurst, D., Appelo, C., 1999. User's guide to PHREEQC (Version 2) - A computer program for speciation, batch-reaction, one-dimensional transport, and inverse geochemical calculations. Water-Resources Investigation Report 99-4259. U.S. Department of the Interior, U.S. Geological Survey.

Parkhurst, D., Appelo, C., 2013. Description of Input and Examples for PHREEQC (Version 3) - A computer program for speciation, batchreaction, one-dimensional transport, and inverse geochemical calculations. Technical Report 6. U.S. Department of the Interior, U.S. Geological Survey. URL: http://pubs.usgs.gov./tm/06/a43.

Rezaei, M., Sanz, E., Raeisi, E., Ayora, C., Vázquez-Suñé, E., Carrera, J., 2005. Reactive transport modeling of calcite dissolution in the fresh-salt water mixing zone. Journal of Hydrology 311, 282-298. 
Rodríguez-Escales, P., van Breukelen, B.M., Vidal-Gavilan, G., Soler, A., Folch, A., 2014. Integrated modeling of biogeochemical reactions and associated isotope fractionations at batch scale: A tool to monitor enhanced biodenitrification applications. Chemical Geology 365, 20-29.

Ruget, F., Duru, M., Gastal, F., 1999. Adaptation of an annual crop model (STICS) to a perennial crop: grassland, in: International symposium modeling cropping systems, pp. 111-112.

Ruget, F., Novak, S., Granger, S., 2006. Du modèle STICS au système ISOP pour estimer la production fourragère. adaptation à la prairie, application spatialisée. Fourrages 186, 241-256.

Sándor, R., Barcza, Z., Hidy, D., Lellei-Kovács, E., Ma, S., Bellocchi, G., 2016. Modelling of grassland fluxes in Europe: Evaluation of two biogeochemical models. Agriculture, Ecosystems \& Environment 215, 1-19.

Senapati, N., Jansson, P.E., Smith, P., Chabbi, A., 2016. Modelling heat, water and carbon fluxes in mown grassland under multi-objective and multicriteria constraints. Environmental Modelling \& Software 80, 201-224.

Shuval, H., 1991. Health guidelines and standards for wastewater reuse in agriculture: Historical perspectives. Water Science and Technology 23, 2073-2080.

Slimani, R., Guendouz, A., Trolard, F., Moulla, A., Hamdi-Haïssa, B., Bourrié, G., 2016. Identification of dominant hydrogeochemical processes for 
groundwaters in the algerian sahara supported by inverse modeling of chemical and isotopic data. HESS 20, 1-23. doi:10.5194/hess-20-1-2016.

Song, Z., Wang, H., Strong, P.J., Li, Z., Jiang, P., 2012. Plant impact on the coupled terrestrial biogeochemical cycles of silicon and carbon: Implications for biogeochemical carbon sequestration. Earth-Science Reviews $115,319-331$.

Song, Z., Zhao, S., Zhang, Y., Hu, G., Cao, Z., Wong, M., 2011. Plant impact on $\mathrm{CO} 2$ consumption by silicate weathering: the role of bamboo. The Botanical Review 77, 208-213.

Sophocleous, M., 2002. Interactions between groundwater and surface water: the state of the science. Hydrogeology journal 10, 52-67.

Stumm, W., Morgan, J., 1970. Aquatic chemistry. John Wiley \& Sons Ltd. Trolard, F., Baillieux, A., Buis, S., Clastre, P., Courault, D., Dangeard, M.L., Virgilio, N.D., Dussouilliez, P., Fleury, J., Jouan, R., Keller, C., Lecharpentier, P., Lecroart, J., Napoleone, C., Mohammed, G., Olioso, A., Reynders, S., Rossi, F., Tennant, M., 2016. PRECOS framework: Measure the impacts of the global changes on soils, water, agriculture on territories to better anticipate the future. Journal of environmental management 181, 590.

Trolard, F., Dangeard, M.L., 2014. Les sols, l'eau et la production agricole: des ressources de base face à l'étalement urbain et aux changements clima- 
tiques, in: Collart Dutilleul, F., Bréger, T. (Eds.), Penser une démocratie alimentaire. INIDA. volume 2, pp. 113-123.

Trolard, F., Dangeard, M.L., de Mordant de Massiac, J.C., Bourrié, G., Lecerf, R., Le Pors, B., Chanzy, A., Dangeard, A., Keller, C., Charron, F., le consortium ASTUCE\& TIC, 2013a. Disparition des habitats naturels et agricoles : quelques enseignements tirés du programme Astuce\&Tic, in: Tatin, L., Wolff, A., Boutin, J., Colliot, E., Dutoit, T. (Eds.), Écologie et conservation d'une steppe méditerranéenne: la plaine de Crau. Éditions Quae, pp. 229-245.

Trolard, F., Reynders, S., Dangeard, M.L., Bourrié, G., Descamps, B., de Mordant de Massiac, J.C., 2013b. Territoires, villes et campagnes face à l'étalement urbain et au changement climatique - Une démarche intégrative pour préserver les sols, l'eau et la production agricole. Éditions Johanet.

Tsiridis, V., Kougolos, A., Kotios, A., Plageras, P., Saratsis, Y., 2009. Wastewater reclamation and reuse. Discuss. Pap. Ser. 15, 139-148.

Valett, H.M., Morrice, J.A., Dahm, C.N., Campana, M.E., 1996. Parent lithology, surface-groundwater exchange, and nitrate retention in headwater streams. Limnol. Oceanogr 41, 333-345.

Van Berk, W., Schulz, H.M., Fu, Y., 2009. Hydrogeochemical modelling of 
CO2 equilibria and mass transfer induced by organic-inorganic interactions in siliciclastic petroleum reservoirs. Geofluids 9, 253-262.

Walker, A.P., Hanson, P.J., De Kauwe, M.G., Medlyn, B.E., Zaehle, S., Asao, S., Dietze, M., Hickler, T., Huntingford, C., Iversen, C.M., et al., 2014. Comprehensive ecosystem model-data synthesis using multiple data sets at two temperate forest free-air CO2 enrichment experiments: Model performance at ambient CO2 concentration. Journal of Geophysical Research: Biogeosciences 119, 937-964.

Wallis, P., Hynes, H., Telang, S., 1981. The importance of groundwater in the transportation of allochthonous dissolved organic matter to the streams draining a small mountain basin. Hydrobiologia 79, 77-90.

Wenzel, S., Cox, P.M., Eyring, V., Friedlingstein, P., 2014. Emergent constraints on climate-carbon cycle feedbacks in the CMIP5 earth system models. Journal of Geophysical Research: Biogeosciences 119, 794-807.

Xiao, J., Chen, J., Davis, K.J., Reichstein, M., 2012. Advances in upscaling of eddy covariance measurements of carbon and water fluxes. Journal of Geophysical Research: Biogeosciences 117.

Yu, G.R., Wen, X.F., Sun, X.M., Tanner, B.D., Lee, X., Chen, J.Y., 2006. Overview of ChinaFLUX and evaluation of its eddy covariance measurement. Agricultural and Forest Meteorology 137, 125-137. 
1042

1043

1044

1045

1046

1047

1048

1049

Zhang, L., Mao, J., Shi, X., Ricciuto, D.M., He, H., Thornton, P.E., Yu, G., Han, S., Li, Y., Yan, J., Hao, Y., Wang, H., 2016. Evaluation of the Community Land Model simulated carbon and water fluxes against observations over chinaflux sites. Agricultural and Forest Meteorology 226-227, 174-185.

Zhang, X., Chen, J., Tan, M., Sun, Y., 2007. Assessing the impact of urban sprawl on soil resources of Nanjing city using satellite images and digital soil databases. Catena 69, 16-30. 
1050

1051

1052

1053

1054

1055

1056

1057

1058

1059

1060

1061

\section{List of Tables}

1 Characteristics of models connecting agronomy, climatology, geochemistry and soil science. . . . . . . . . . . . 56

2 Biogeochemical processes modelled and necessary data for the "Irrigation water - atmosphere - plant - soil - groundwater" system. . . . . . . . . . . . . . . . . 57

3 Mass balance of inputs by irrigation water and uptakes by Crau's hay. . . . . . . . . . . . . . . . 57

4 Flux of $\mathrm{P}$ in $\mu \mathrm{mol} / \mathrm{m}^{2}$ through simulation steps of biogeochemical modelling. . . . . . . . . . . . . . . . . . . . . . . 58

$5 \quad$ Comparison of simulated soil solution for steps S1, S3 and S4 with groundwater, concentration in $\mathrm{mmol} / \mathrm{l}$. . . . . . . 58 
1062 List of Figures

$1063 \quad 1$ Factors acting in the system . . . . . . . . . . . . 54

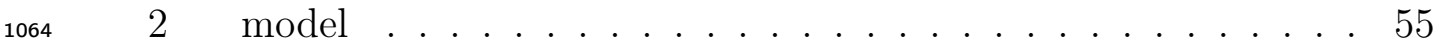

10653 Diagrams of Saturation Index of solutions with respect to cal-

$1066 \quad$ cite and gypsum . . . . . . . . . . . . . . . 59

$1067 \quad 4 \quad \mathrm{Ca}$ and $\mathrm{C}$ mass balance and $\mathrm{pH}$ changes . . . . . . . . . . 60

10685 Comparaison of simulated and measured annual values of ground-

1069

water ..................... . . . 61 


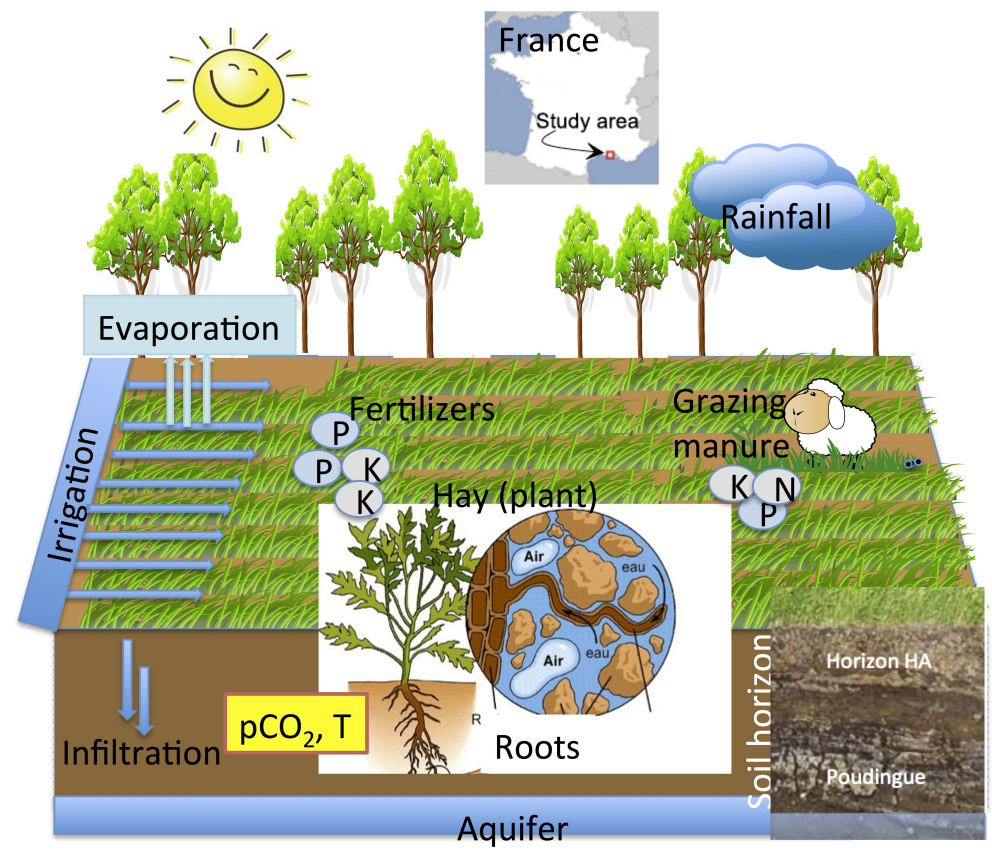

Figure 1: Factors affecting the chemical composition of water in the Crau's agrosystem. 


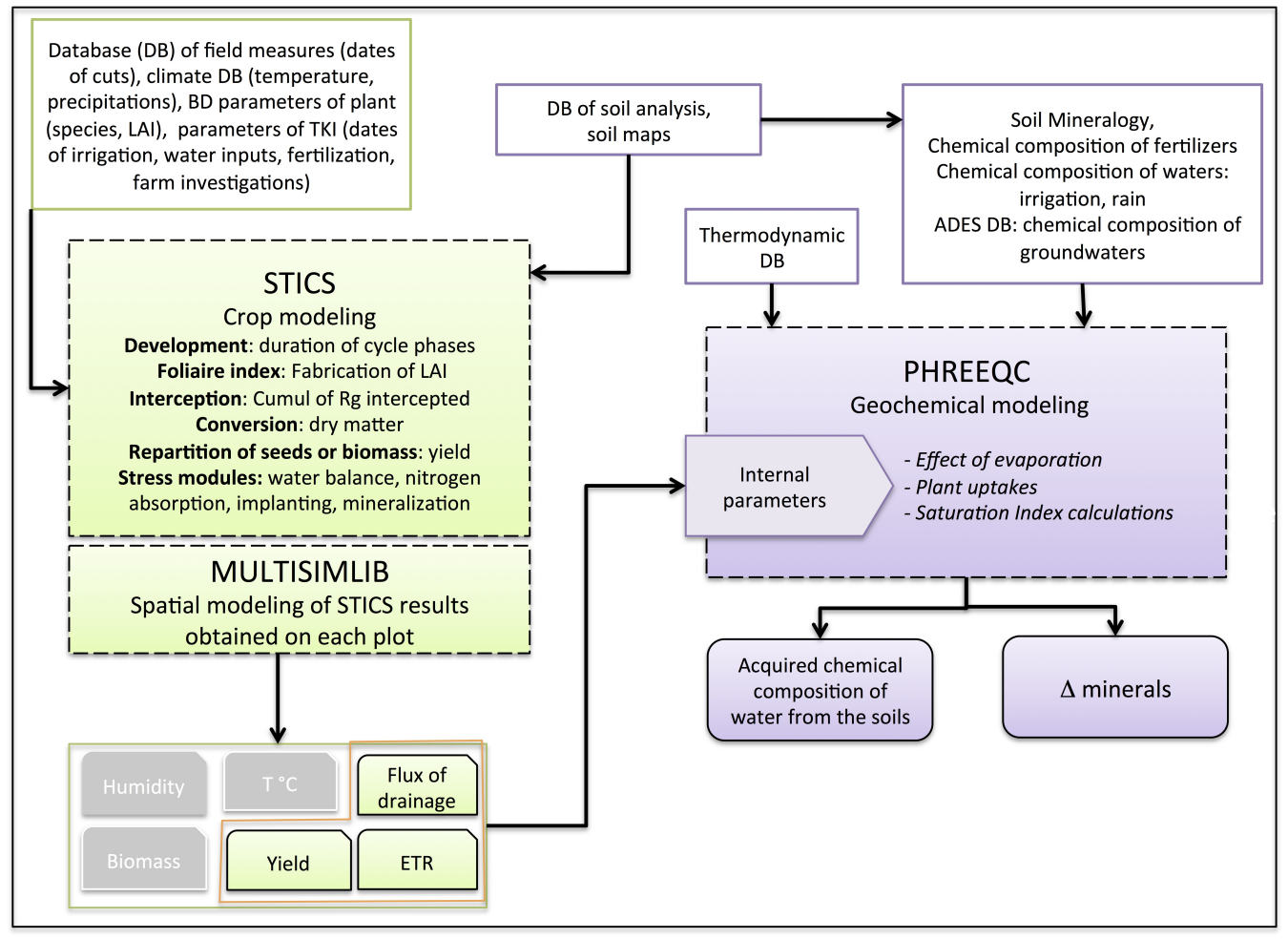

Figure 2: Architecture of the combination of the crop model STICS and the geochemical model PHREEQC, necessary data for inputs and main outputs obtained after simulations. 
Table 1: Characteristics of models connecting agronomy, climatology, geochemistry and soil science.

\begin{tabular}{|c|c|c|c|c|c|c|}
\hline Modelling/Model & Aim & Agr. & Clim. & Geoch. & Soil Sci. & Ref. \\
\hline $\begin{array}{l}\text { Hydrological and bio- } \\
\text { geochemical model }\end{array}$ & $\mathrm{N}$ cycling and transport & $\mathrm{x}$ & $\mathrm{x}$ & $\mathrm{x}$ & $\mathrm{x}$ & 1 \\
\hline $\begin{array}{l}\text { Hydrological and bio- } \\
\text { geochemical model }\end{array}$ & Solute retention & $\mathrm{x}$ & & $\mathrm{x}$ & $\mathrm{x}$ & 2 \\
\hline $\begin{array}{l}\text { Biogeochemical models: } \\
\text { PaSim /Biome-BGC } \\
\text { MuSo }\end{array}$ & C cycle & $\mathrm{x}$ & $\mathrm{x}$ & $\mathrm{x}$ & $\mathrm{x}$ & 3 \\
\hline $\begin{array}{l}\text { Terrestrial biosphere } \\
\text { models (TBMs) }\end{array}$ & C cycle & $\mathrm{x}$ & $\mathrm{x}$ & & & 4 \\
\hline $\begin{array}{l}\text { Biogeochemical mod- } \\
\text { elling }\end{array}$ & $\begin{array}{l}\text { Nutrients cycling af- } \\
\text { fected by wildfire }\end{array}$ & $\mathrm{x}$ & & $\mathrm{x}$ & & 5 \\
\hline $\begin{array}{l}\text { Hydrochemical model: } \\
\text { AHM }\end{array}$ & $\begin{array}{l}\text { Daily stream chemical } \\
\text { composition and its re- } \\
\text { action to } \mathrm{N} \text { deposition }\end{array}$ & $\mathrm{x}$ & $\mathrm{x}$ & $\mathrm{x}$ & $\mathrm{x}$ & 6 \\
\hline $\begin{array}{ll}\text { SOILVEG- } & \text { FOR- } \\
\text { GRO/NUCSAM } & \end{array}$ & $\begin{array}{l}\text { Effects of multiple stres- } \\
\text { sors on forest stands }\end{array}$ & $\mathrm{x}$ & $\mathrm{x}$ & $\mathrm{x}$ & & 7 \\
\hline $\begin{array}{lr}\text { "Ecosystem } & \text { model } \\
\text { (DayCent)/ } & \text { geo- } \\
\text { chemical } & \text { model } \\
\text { (PHREEQC)" } & \\
\end{array}$ & $\begin{array}{l}\text { "Atmospheric deposi- } \\
\text { tion impacts " }\end{array}$ & $\mathrm{x}$ & $\mathrm{x}$ & $\mathrm{x}$ & $\mathrm{x}$ & 8 \\
\hline
\end{tabular}

Agr. = Agronomy / Ecology / Biology; Clim. = Climatology; Geoch. = Geochemistry; Soil Sci. = Soil Science and Hydrology.

1. (Cirmo and McDonnell, 1997); 2. (Valett et al., 1996; Dahm et al., 1998); 3. (Sándor et al., 2016); 4. (Xiao et al., 2012; Cramer et al., 1999; Jung et al., 2007; Huntzinger et al., 2012); 5. (Fultz et al., 2016); 6. (Meixner et al., 2000); 7. (van Heerden et al., 1995; Mohren and van de Veen, 1995); 8. (Hartman et al., 2007). 
Table 2: Biogeochemical processes modelled and necessary data for the "Irrigation water - atmosphere - plant - soil - groundwater" system.

\begin{tabular}{|c|c|}
\hline Processes & Equation and necessary data \\
\hline Irrigation water & Water analysis \\
\hline $\begin{array}{l}\text { Concentration by } \\
\text { evaporation }\end{array}$ & $\begin{array}{l}f_{c}=\frac{I+P}{I+P-E T}=\frac{I+P}{D} \\
I=\text { Irrigation, } P=\text { Precipitation, } E T=\text { Evaporation } \\
D=\text { Drainage, } D=I+P-E\end{array}$ \\
\hline $\mathrm{pCO}_{2}$ influence & $\mathrm{pCO}_{2}$ and soil temperature $(\mathrm{t})$ \\
\hline Fertilizers dissolution & Stoichiometry of Fertilizers P - K, fertilizers analysis \\
\hline $\begin{array}{l}\text { Rate of fertilizers } \\
\text { dissolution }\end{array}$ & $\begin{array}{l}\text { Calibration by } \mathrm{K} \text { uptake } \\
n=D \rho_{w}[\mathrm{~K}]_{d}-I \rho_{w}[\mathrm{~K}]_{0}+R[\mathrm{~K}]_{b} \\
R=\text { Yield, } D=\text { Drainage, } \rho_{w}=\text { specific mass of water. }\end{array}$ \\
\hline Mineral uptakes & $\begin{array}{l}\text { Balance of absorbed elements and excreted protons : } \\
\Sigma\left[\mathrm{H}^{+}\right]=\left[\mathrm{Na}^{+}\right]+\left[\mathrm{K}^{+}\right]+2\left[\mathrm{Ca}^{2+}\right]+2\left[\mathrm{Mg}^{2+}\right]-\left[\mathrm{NO}_{3}^{-}\right]-\left[\mathrm{H}_{2} \mathrm{PO}_{4}^{-}\right]- \\
2\left[\mathrm{SO}_{4}^{-2}\right]\end{array}$ \\
\hline $\begin{array}{l}\text { Soil / solution } \\
\text { interactions }\end{array}$ & $\begin{array}{l}\text { Minerals nature and thermodynamic conditions (equilibrium / } \\
\text { non equilibrium / kinetic, } \mathrm{pCO}_{2} \text {, temperature). }\end{array}$ \\
\hline $\begin{array}{l}\text { Output to } \\
\text { groundwater }\end{array}$ & $\rho_{w}[\mathrm{E}]_{d}=\frac{I}{D} \rho_{w}[\mathrm{E}]_{I}-\frac{R}{D}[\mathrm{E}]_{b}+v_{E} \frac{n}{D}$ \\
\hline
\end{tabular}

Table 3: Mass balance of inputs by irrigation water and uptakes by Crau's hay.

\begin{tabular}{llllllll}
\hline & Cut & Ca & \multicolumn{2}{c}{$\begin{array}{l}\mathrm{Mg} \\
/ \mathrm{mmol} / \mathrm{m}^{2}\end{array}$} & $\mathrm{~K}$ & $\mathrm{Na}$ & $\mathrm{S}$ \\
\hline$Q_{I}$ & Cut1 & 2.862 & 0.648 & 0.001 & 0.046 & 0.799 & 1.077 \\
& Cut2 & 2.707 & 0.757 & 0.004 & 0.042 & 0.757 & 1.093 \\
& Cut3 & 2.615 & 0.741 & 0.002 & 0.040 & 0.668 & 0.893 \\
\hline \multirow{2}{*}{$Q_{b}$} & Cut1 & -0.067 & -0.025 & -0.019 & -0.125 & -0.041 & -0.016 \\
& Cut2 & -0.078 & -0.031 & -0.021 & -0.107 & -0.031 & -0.018 \\
& Cut3 & -0.085 & -0.033 & -0.021 & -0.082 & -0.040 & -0.016 \\
\hline \multirow{2}{*}{ Balance } & Cut1 & 2.795 & 0.623 & $\mathbf{- 0 . 0 1 8}$ & $\mathbf{- 0 . 0 7 9}$ & 0.758 & 1.060 \\
& Cut2 & 2.629 & 0.726 & $\mathbf{- 0 . 0 1 7}$ & $\mathbf{- 0 . 0 6 5}$ & 0.726 & 1.075 \\
& Cut3 & 2.530 & 0.708 & $\mathbf{- 0 . 0 1 9}$ & $\mathbf{- 0 . 0 4 2}$ & 0.628 & 0.877 \\
\hline
\end{tabular}

$Q_{I}$ Fluxes brought by irrigation; $Q_{b}$ Fluxes exported by hay. 
Table 4: Flux of $\mathrm{P}$ in $\mu \mathrm{mol} / \mathrm{m}^{2}$ through simulation steps of biogeochemical modelling.

\begin{tabular}{llccccc}
\hline & Cut & $\begin{array}{c}\text { Irrigation } \\
\text { water }\end{array}$ & $\begin{array}{c}\text { Fertilizers } \\
\text { addition }\end{array}$ & $\begin{array}{c}\text { Root } \\
\text { uptake }\end{array}$ & $\begin{array}{c}\text { Precipitated as } \\
\text { hydroxy-apatite }\end{array}$ & Groundwater \\
\hline \multirow{2}{*}{2012} & C1 & 0 & 54 & -32 & -22 & 0.4 \\
& C2 & 0 & 81 & -55 & -25 & 0.3 \\
& C3 & 0 & 56 & -53 & -2 & 0.4 \\
\hline \multirow{2}{*}{2013} & C1 & 0 & 64 & -32 & -31 & 0.4 \\
& C2 & 0 & 67 & -40 & -26 & 0.3 \\
& C3 & 0 & 56 & -53 & -2 & 0.4 \\
\hline \multirow{2}{*}{2014} & C1 & 0 & 73 & -37 & -36 & 0.5 \\
& C2 & 0 & 120 & -66 & -53 & 0.3 \\
& C3 & 0 & 96 & -92 & -4 & 0.4 \\
\hline \multirow{2}{*}{2015} & C1 & 0 & 98 & -49 & -48 & 0.4 \\
& C2 & 0 & 110 & -85 & -30 & 0.3 \\
& C3 & 0 & 88 & -57 & -30 & 0.3 \\
\hline
\end{tabular}

Table 5: Comparison of simulated soil solution for steps S1, S3 and S4 with groundwater, concentration in $\mathrm{mmol} / \mathrm{l}$.

\begin{tabular}{lllllllll}
\hline & $\mathrm{Ca}$ & $\mathrm{Mg}$ & $\mathrm{Cl}$ & $\mathrm{K}$ & $\mathrm{Na}$ & $\mathrm{S}$ & $\mathrm{C}$ & $\mathrm{N}$ \\
\hline Aquifer av. & 3.443 & 0.473 & 0.640 & 0.033 & 0.639 & 1.225 & 5.403 & 0.625 \\
Aquifer sd. & 0.19 & 0.05 & 0.01 & 0.01 & 0.05 & 0.13 & 0.80 & 0.12 \\
\hline S1 & 2.718 & 0.774 & 0.648 & 0.031 & 0.995 & 1.122 & 5.939 & 0.079 \\
S3 & 2.629 & 0.707 & 0.660 & 0.038 & 0.824 & 1.337 & 5.939 & 0.625 \\
S4 & 3.206 & 0.707 & 0.660 & 0.038 & 0.824 & 1.337 & 5.616 & 0.625 \\
\hline Inverse model & 3.633 & 0.473 & 0.660 & 0.033 & 0.639 & 1.337 & 5.508 & 0.625 \\
\hline
\end{tabular}

$\mathrm{S} 1=$ soil solution after evaporation, equilibration with calcite and $\mathrm{CO}_{2(\mathrm{~g})} ; \mathrm{S} 3=$ soil solution after fertilizers (N, P, K) dissolution and plant uptake; $\mathrm{S} 4=$ soil solution after equilibration with calcite, hydroxy-apatite and $\mathrm{CO}_{2(\mathrm{~g})}$. Inverse model optimizes mass transfer to account for transformation of solution S3 to the aquifer. 

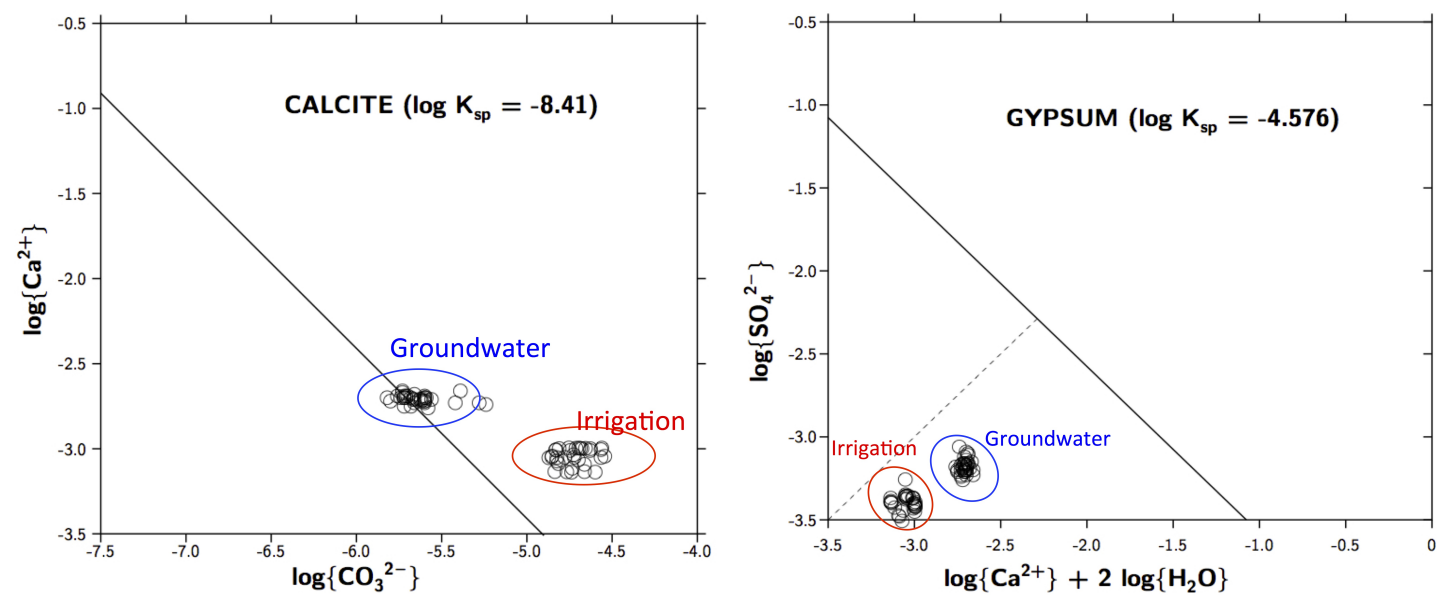

Figure 3: Diagrams of Saturation Indices $(S I)$ of solutions with respect to calcite (left) and gypsum (right) of irrigation water (red) and groundwater (blue). Points above the equilibrium line indicate oversaturation and points below undersaturation. 

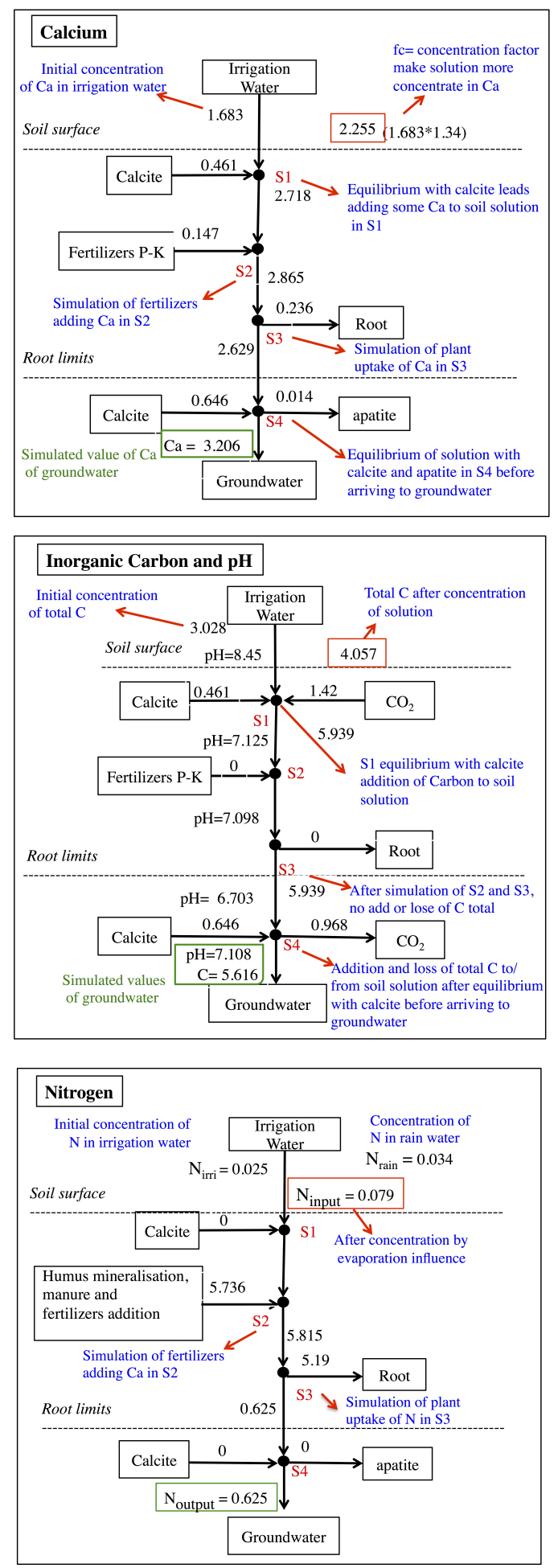

60

Figure 4: Mass balance and fluxes of $\mathrm{Ca}$, inorganic $\mathrm{C}$, and $\mathrm{N}$ and $\mathrm{pH}$ variations for 2015 Cut1 in $\mathrm{mmol} / \mathrm{kg}$ for $1 \mathrm{~kg}$ of water draining till the aquifer through the soil horizons in the Crau's agrosystem. 

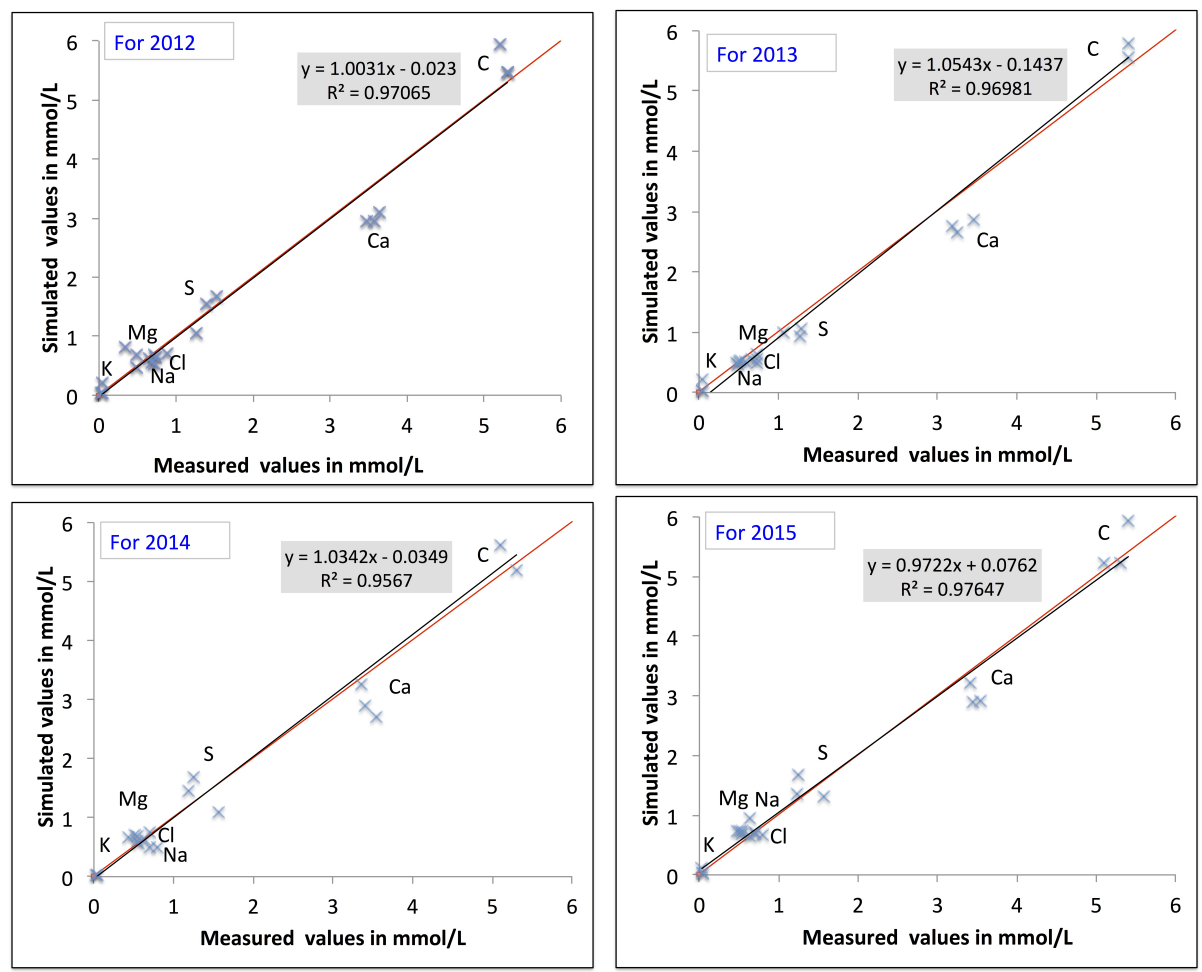

Figure 5: Comparaison of simulated and measured values of chemical composition of the Crau's groundwater $(\mathrm{C}, \mathrm{Ca}, \mathrm{Cl}, \mathrm{K}, \mathrm{Mg}, \mathrm{Na}, \mathrm{S}$ in $\mathrm{mmol} / \mathrm{L})$. Red line = 1:1 line; black line $=$ regression line of data. 